\title{
A Scientometrics Review on Farmland Abandonment Research
}

\author{
Yingqian Huang ${ }^{1}$, Fengqin $\mathrm{Li}^{2}$ and Hualin $\mathrm{Xie}^{1, *}$ \\ 1 Institute of Ecological Civilization, Jiangxi University of Finance and Economics, \\ Nanchang 330013, China; hyq162545@163.com \\ 2 School of Tourism and Urban Management, Jiangxi University of Finance and Economics, \\ Nanchang 330032, China; lfq0904@163.com \\ * Correspondence: xiehualin@jxufe.edu.cn
}

Received: 9 April 2020; Accepted: 3 August 2020; Published: 5 August 2020

check for updates

\begin{abstract}
Using the Web of Science database, 1498 research articles published between 1900 and 2019 on the subject of farmland abandonment were retrieved. With the help of the SciMAT tool, a theme strategic diagram, overlay map and evolution map represented by keywords were constructed, and the strategic coordinate analysis and data flow analysis methods were used to analyze the research themes, evolutionary states and paths of farmland abandonment in different research time periods. The results show the following: (1) Research on farmland abandonment has rapidly grown in the past ten years, the development of studies on farmland abandonment has become more mature, and the research topics and content have tended to solidify; (2) The research topics of studies on farmland abandonment are mostly centered on forests, patterns, landscapes, land use changes, climate change, etc. The research topics have had strong continuity and few new research hotspots; (3) The study of the ecological environment effect of farmland abandonment is the basic research direction in the field of farmland abandonment and will continue to become a research hotspot; (4) Farmland abandonment has become an important part of the research on land use change and ecosystem processes; (5) The driving force of farmland abandonment includes natural, social and economic factors, among which the socioeconomic factors are the most important driving force, and will continue to be a research hotspot. Finally, this study concludes that the research directions on farmland abandonment in future should strengthen the quantitative assessment of environmental effects of farmland abandonment, information extraction and multiscale simulation monitoring, trend prediction and risk assessment.
\end{abstract}

Keywords: farmland abandonment; land use change; theme evolution; strategic coordinate analysis; data flow

\section{Introduction}

Global urbanization and industrialization have resulted in a rapid economic development, so that the income gap between the agricultural sector and the non-agricultural sector has gradually been widened, many countries have experienced profound changes in the income and structure of rural households [1]. Moreover, one of the most obvious changes is that, driven by economic benefits, many rural laborers leave their home areas to find work, resulting in a shortage of agricultural labor, the aging of agricultural production in rural areas and the marginalization of farmland [1]. In addition, the rising agricultural operating costs and unbalanced land investment are is reflected in farmers' decision-making response to land use, which is mainly consists in the abandonment of the remote, scattered and inefficient farmland [2]. To systematically understand the evolution of the theme of abandonment, the term "abandonment" used in this article covers the abandonment of farmland, 
grassland and pasture, as well as the inefficient use of farmland due to the extensive management of farmland, seasonal idleness and long-term idleness [3]. From existing research, developed countries such as the United States, Australia, Japan and those in Europe are the areas with the most extensive distribution of farmland abandonment, while China's mountainous areas, Latin America, Southeast Asia and other regions also have obvious abandonment phenomena [3-6]. From this point of view, farmland abandonment has become a socioeconomic phenomenon prevailing in various countries around the world.

Farmland abandonment is a complex process involving all aspects of the economy, environment and society and is usually linked to the socioeconomic characteristics of rural areas $[7,8]$. The reduction in the area of farmland due to abandonment affects the goods and services provided by farmland and changes the status of rural land use, the agricultural landscape and farmers' livelihoods. In addition, farmland abandonment may produce various ecological and socioeconomic effects and set in motion positive and negative evolutionary processes. One positive impact is the expansion of natural vegetation species adapted to local natural conditions, followed by the natural succession of grasslands or secondary forests [9], providing potential for ecological restoration and increased carbon sequestration $[10,11]$, as well as soil restoration, improved nutrient cycling and increased biodiversity $[12,13]$. However, farmland abandonment can also lead to shallow landslide issues [14,15], increased fire risk [16], soil erosion and desertification [17] and a loss of biodiversity and cultural heritage $[18,19]$. Therefore, the uncertainty regarding the effects of farmland abandonment provides multiple possible ways for simulating the succession process of different scenarios, which is of great significance in exploring the diversified development of the themes of farmland abandonment.

To date, the research on farmland abandonment is mainly concentrated in driving forces, temporal and spatial distribution characteristics and coping strategies. Research on the driving mechanism of farmland abandonment has been a hot topic in geography, economics and ecology [20-22]. Especially in Europe and Japan, the development of urbanization and industrialization is considered to be the most fundamental driving force for farmland abandonment, and the migration of rural labor is a direct cause of farmland abandonment [3]. Secondary drivers of farmland abandonment include region-specific factors such as the marginalization of farmland, related land ownership and taxation systems $[15,23]$. For example, the main driving force of the abandonment of farmland in Eastern Europe is institutional change. Coincidentally, under China's current land management system, especially given the inadequate rural social security system, farmers who still have a "land complex" would rather abandon their land than transfer land out. Even if there is substitute farming between relatives, friends and neighbors, marginal farmland abandonment is still inevitable.

Although agricultural production activities still exist in some valleys and plateau areas, large-scale farmland abandonment occurs on steep hillsides [14,17], and the trend of farmland abandonment continues to increase [24]. The mountainous regions are the most common areas of farmland abandonment [25-35]. In China, at the county level, the highest rate of farmland abandonment is in the mountainous areas of the Yangtze River Basin, and the spatial distribution shows a " $\mathrm{T}$ " pattern rotated 90 degrees counterclockwise [35]. The earliest farmland abandonment in China began in 1990, but large-scale farmland abandonment in mountainous counties mainly occurred after 2005 [35]. In addition, farmland abandonment in Europe appeared early and developed rapidly. Large-scale farmland abandonment occurred in the second half of the 20th century and research on this phenomenon is mainly focused on the 1990s.

The research on coping strategies for farmland abandonment is mostly conducted from the perspective of the government and farmers and through the introduction of related policies to ease the process of abandonment. In particular, the EU's agricultural development policy and Japan's direct subsidy policy for mountainous areas play an important role in alleviating the farmland abandonment [3]. In Asia and Latin America, technologies are being adopted to increase the intensification of farmland use while reducing dependence on farmland in mountainous areas, thereby promoting forest vegetation restoration in mountainous areas [3]. It should be noted that there 
have been many academic theoretical studies on farmland abandonment in China, but there are no authoritative national or local policies to alleviate farmland abandonment.

Although there have been reviews on farmland abandonment research, they are all qualitatively combing the literature and cannot comprehensively reveal the diversified content of farmland abandonment. Therefore, it is particularly important to use bibliometric methods to quantitatively analyze the characteristics of the literature in the field of farmland abandonment and to objectively evaluate the subject's research status and development history. In recent years, researchers have adopted CiteSpace and VOSviewer, two scientific map drawing tools, when researching the evolution of topics, but neither tool can present the dynamic characteristics and evolution status of farmland abandonment. SciMAT is unique in displaying evolution maps, strategy maps and clustering network maps and can track the dynamic evolution path of research topics from a time series [36].

To date, there are few studies on the use of bibliometric methods in domestic and foreign studies on farmland abandonment, and no research has explored the dynamic evolution path of the topic of farmland abandonment. In view of this, this article uses SciMAT as the main map drawing tool, the related publications in the field of farmland abandonment in the Web of Science database as the research object and keywords to characterize the research theme. With the help of the scientific analysis tool SciMAT, the research topics and their evolution paths in different periods are analyzed to detect the evolution patterns of the research topics on farmland abandonment.

\section{Research Methods and Data Sources}

\subsection{Analysis Framework and Working Principle of SciMAT}

Figure 1 shows the analysis framework of the evolution of the research topic, which is mainly divided into two parts: research method, data source and processing. Disciplinary theme evolution path analysis refers to the development and change processes of the research theme represented by keywords in the time dimension to identify the theme evolution patterns and development trends. The strategic diagram analysis method and data flow analysis method can be used to analyze and display the evolution of the theme of farmland abandonment [37].

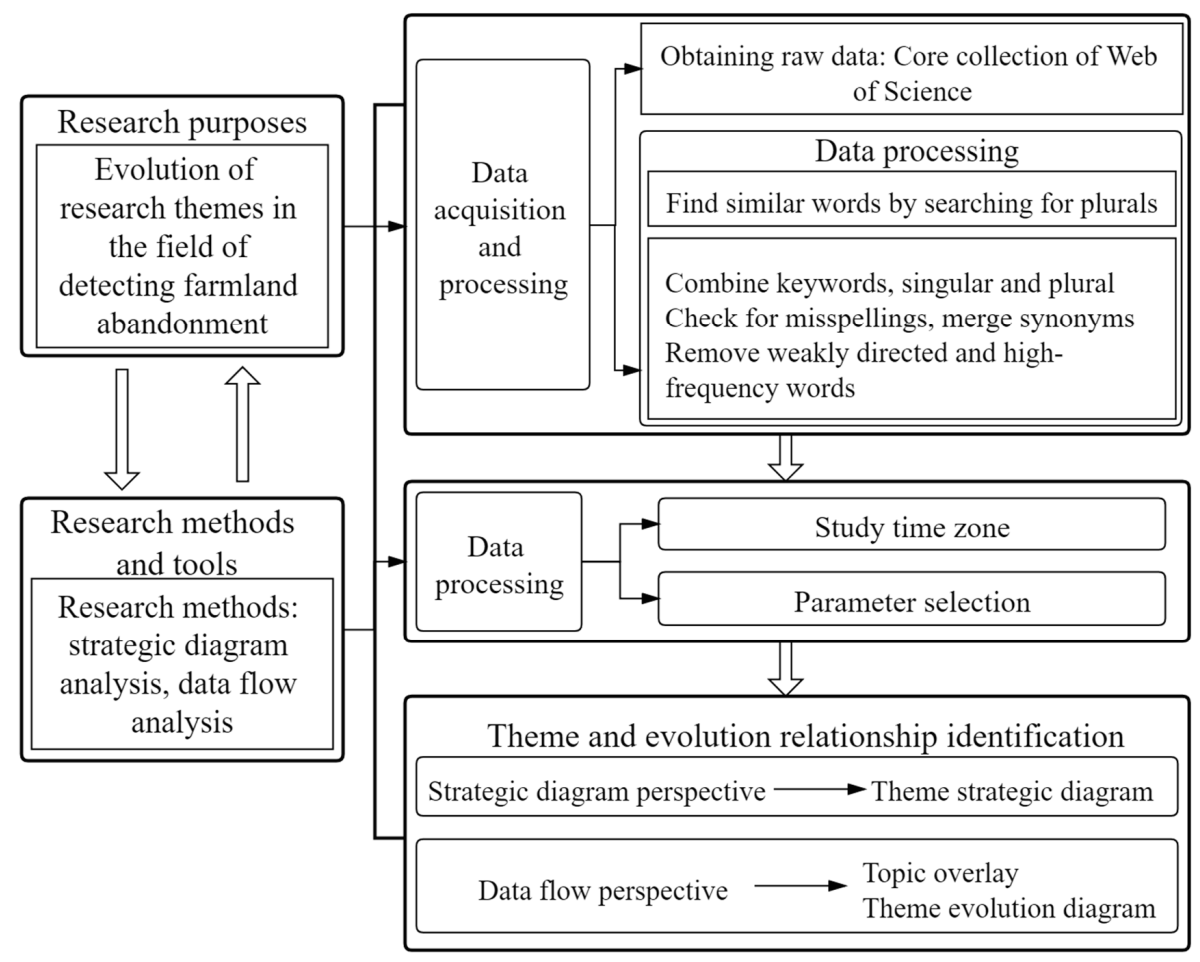

Figure 1. Farmland abandonment theme evolution path analysis framework. 


\subsubsection{The Advantages and Disadvantages of SciMAT}

SciMAT software (https://sci2s.ugr.es/scimat/) was developed by a research group at the University of Granada [38]. It combines science mapping and performance analysis techniques in order to study a research field and visualize and identify specific or general topics/themes and their thematic evolution [36]. The main advantages of SciMAT are: (a) SciMAT helps the analyst to carry out the different steps of the science mapping workflow, from data acquisition and preprocessing to the visualization and interpretation of the results; (b) SciMAT incorporates methods to build most the bibliometric networks, different similarity measures to normalize them and build the maps using clustering algorithms and different visualization techniques useful for interpreting the output; (c) SciMAT implements a wide range of preprocessing tools such as detecting duplicate and misspelled items, time slicing, data reduction and network preprocessing; (d) SciMAT allows the analyst to perform a science mapping analysis in a longitudinal framework in order to analyze and track the evolution of a research area [38]. However, SciMAT also has limitations, mainly including two aspects [38]. One aspect is that the generated mapping depends on the selected parameters. Therefore, it has greater subjectivity. Another aspect is that it is easy to introduce methodological bias in the process of co-word analysis.

\subsubsection{Strategic Diagram}

SciMAT uses two different tools to visualize the detected themes: strategic diagram and thematic network. Each theme can be characterized by two measures: centrality and density. Centrality measures the degree of interaction of a network with other networks and can be defined as $c=10 * \sum e_{u v}$, with $u$ a keyword that belongs to the theme and $v$ a keyword that belongs to other themes [38]. Centrality measures the strength of external ties to other themes. This value can be taken as a measure of the importance of a theme in the development of the entire research field analyzed. The density measures the internal strength of the network and can be defined as $d=100\left(\sum e_{i j} / n\right)$, where $i$ and $j$ are keywords belonging to the theme and $n$ the number of keywords in the theme [38]. Density measures the strength of internal ties among all the keywords that describe the research theme. This value can be understood as a measure of the theme's development. Once the centrality and density rankings have been calculated, the themes can be laid out in a strategic diagram.

A strategic diagram is a two-dimensional space built by plotting themes according to their centrality and density rank values (if we use median for classifying clusters) or values (if we use mean) along two axis, $x$-axis centrality, $y$-axis density [37]. Given both measurements, the field of farmland abandonment research can be visualized as a set of research themes, mapped in a two-dimensional strategic diagram (see Figure 2). Therefore, the strategic diagram can be classified into four quadrants.

Motor themes: The theme of this quadrant cluster, with high density and centrality, is characterized by strong evolution and represents a well-developed and important theme.

Highly developed and isolated themes: The theme in the upper-left quadrant have well-developed internal ties, but unimportant external ties and so are of only marginal importance for the field. Such themes are mature in the field but are not research centers and are not important for current development prospects.

Emerging or declining themes: Themes in the lower-left quadrant are both weakly developed and marginal. The themes in this quadrant have low density and centrality. Such themes are on the fringe of research and are generally the subject of emerging or impending recessions.

Basic and transversal themes: Themes in the lower-right quadrant cluster is the basic theme of this research field. It has great influence in the field, but it has not been well developed and has great development potential. 


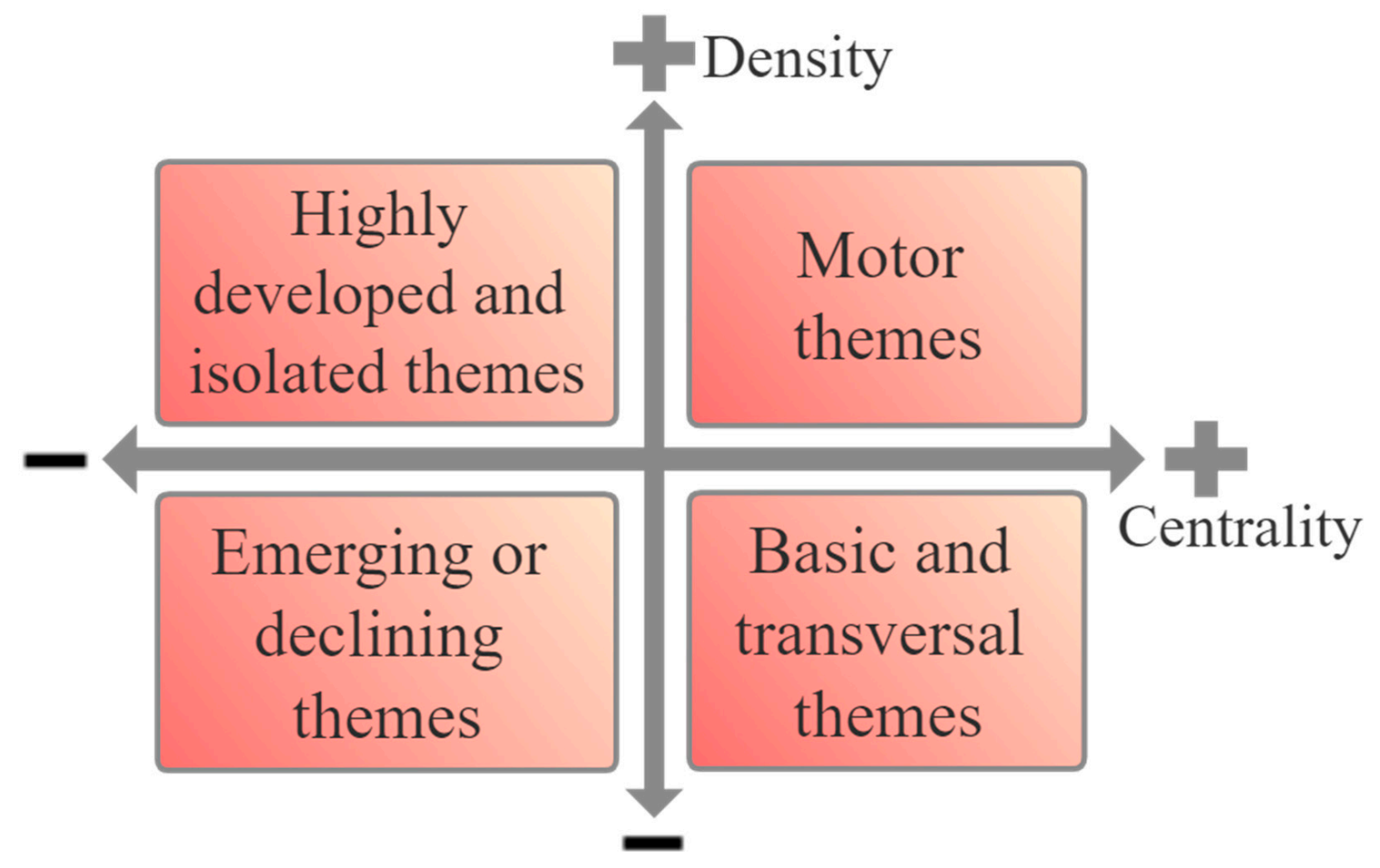

Figure 2. Strategic diagram.

\subsubsection{Thematic Areas: The Evolution of Themes}

If the raw data are divided into different consecutive groups of years (i.e., subperiods), the evolution of the research field under study can be analyzed. A thematic area is defined as a group of evolved themes across different subperiods. The theme evolution map is used to reveal the results of the theme evolution over time. For example, in Figure 3 a we can observe two different thematic areas delimited by different color-shadows, one composed of themes Theme $\mathrm{A}^{1}$ and Theme $\mathrm{A}^{2}$ and the other composed of themes Theme $\mathrm{B}^{1}$, Theme $\mathrm{B}^{2}$ and Theme $\mathrm{C}^{2}$. Theme $\mathrm{D}^{1}$ is discontinued, and Theme $\mathrm{D}^{2}$ is considered to be a new theme. However, in Figure $3 b$, the topic coverage map represents the number of topics with the number of keywords and shows the replacement of old and new research topics in the field and the stability of the research field in the form of data streams. The circles represent the periods and their number of associated keywords. The horizontal arrow represents the number of keywords shared by both periods and, in parentheses, the similarity index between them is shown. The upper-incoming arrow represents the number of new keywords in period 2, and the upper-outgoing arrow represents the keywords that are present in period 1 , but not in period 2 . 


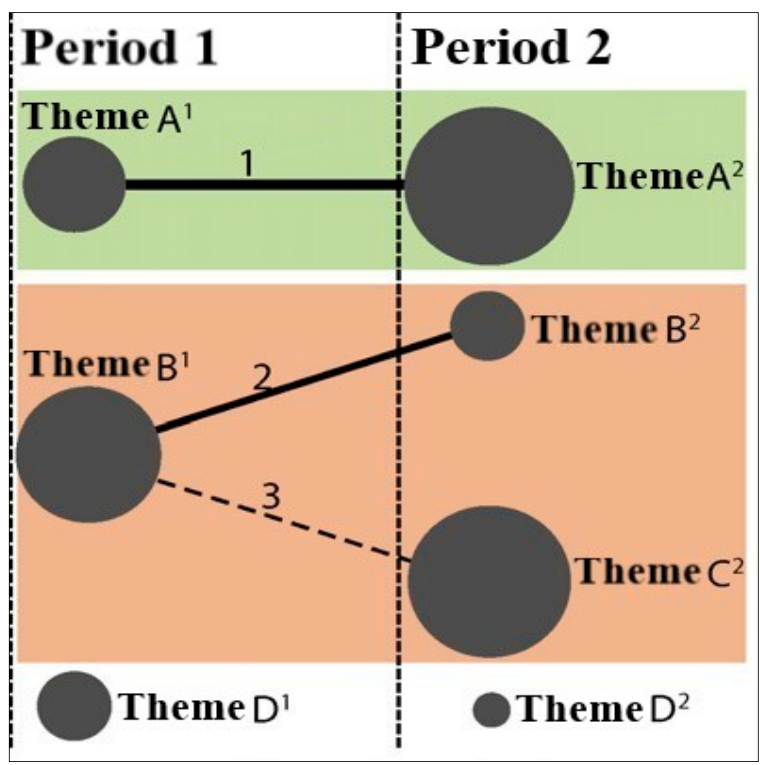

(a)

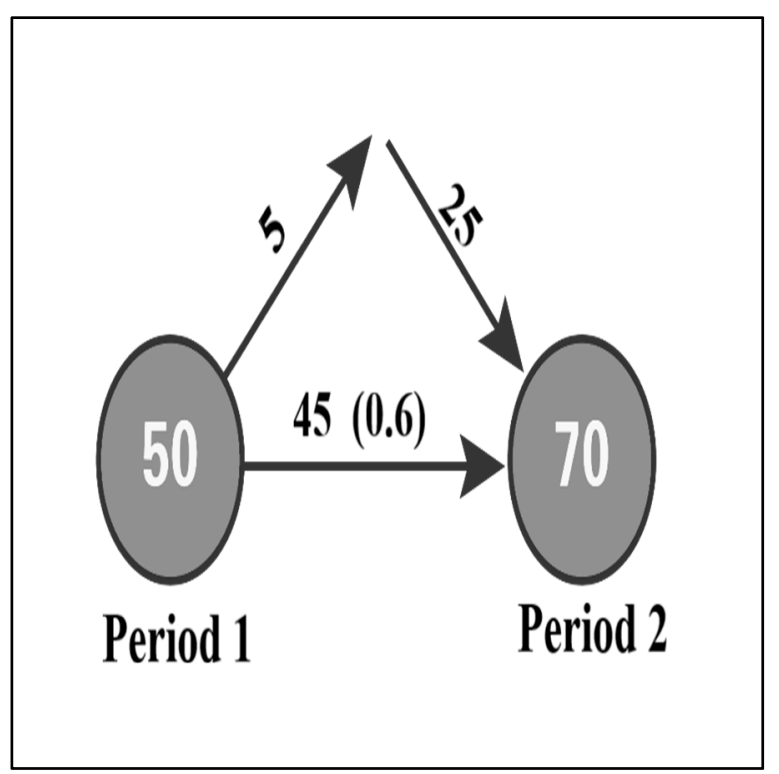

(b)

Figure 3. Examples of evolution. (a) Thematic evolution; (b) stability between periods.

\subsection{Data Acquisition and Processing}

The data in this article came from the core collection of the Web of Science. The specific search strategy was "TS = ("farmland abandonment" or "agricultural land abandonment" or "cropland abandonment" or "rural land abandonment" or "land* abandonment")". The search was conducted on December 31, 2019. The publication year was not limited. The document type was Article, the language was all languages, and the search period was "1900-2019". After deduplication and the removal of irrelevant data, a total of 1498 papers were obtained, and the data were downloaded and saved in a text format that SciMAT can read directly.

Data cleaning refers to the preparation of data and preprocessing before the acquired data are processed and analyzed. SciMAT comes with a 'find similar words by plurals' cleaning function, you can choose automatic cleaning and manual cleaning. Through the automatic cleaning function, which can help merge the singular and plural forms of keywords, manually check for spelling errors and merge keywords with different spellings, but the same meaning.

\subsection{Research Time Period}

The development evolution analysis can be tracked year-by-year in time series or be divided into different stages. The annual distribution of document number reflects the overall situation and research trends, and the latter shows the overall trend characteristics by describing different development stages. The two methods are combined in this study.

From 1900 to 2019, despite the slight fluctuations in the number of published research documents on farmland abandonment, the overall trend continued to grow (See Figure 4). In this study, the time span of the literature collection is large and the amount of literature regarding the early stage of farmland abandonment is small. Therefore, the combination of literature volume and fixed time window was adopted. Due to the small number of early publications in the field of farmland abandonment, in order to avoid the smoothness of the data and to ensure the balance of the data in different stages, this study uses 1903-2004, 2005-2011, 2012-2016 and 2017-2019, respectively as first to fourth research time period (see Figure 5). 


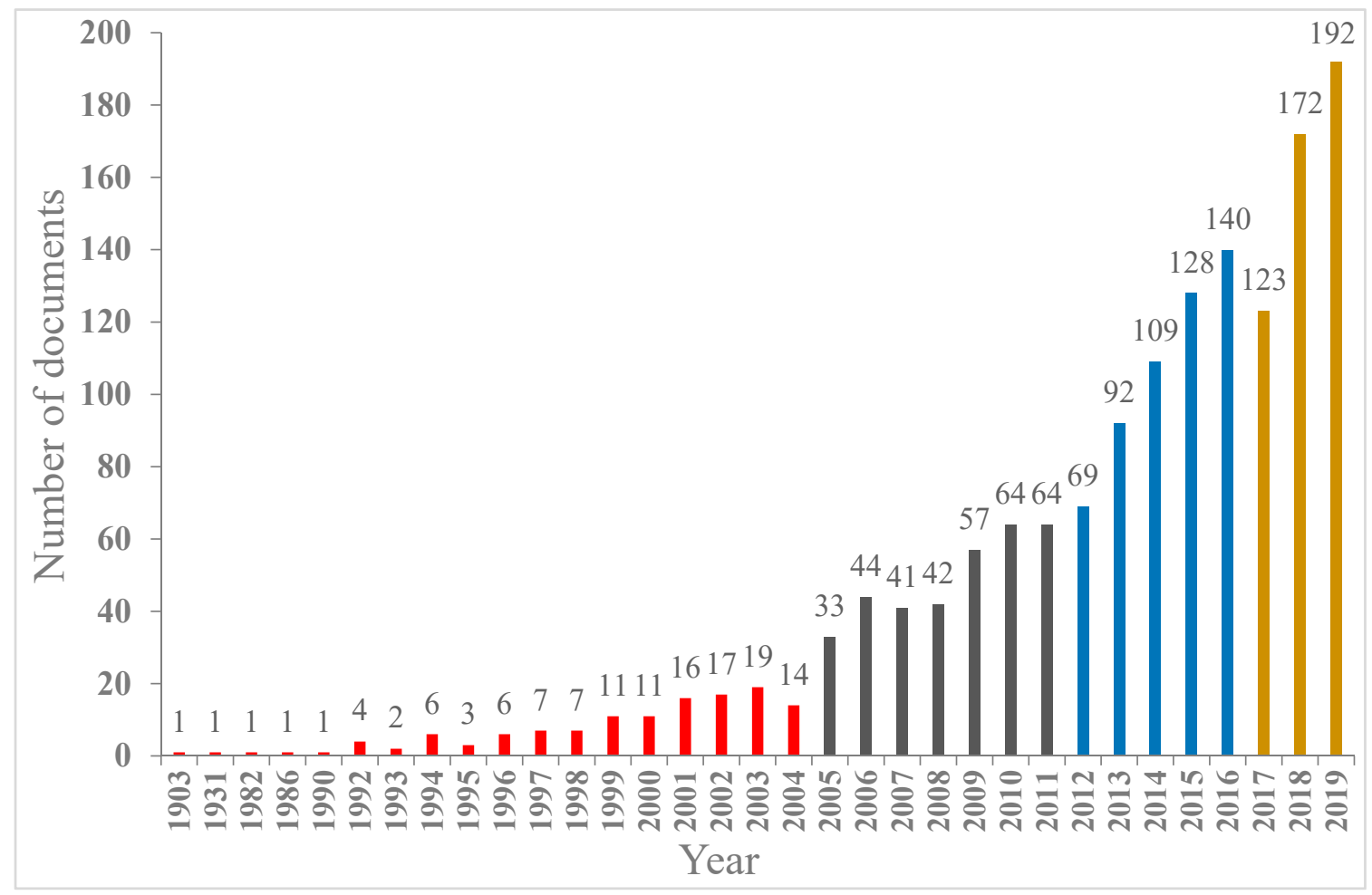

Figure 4. Farmland abandonment research documents published from 1903 to 2019.

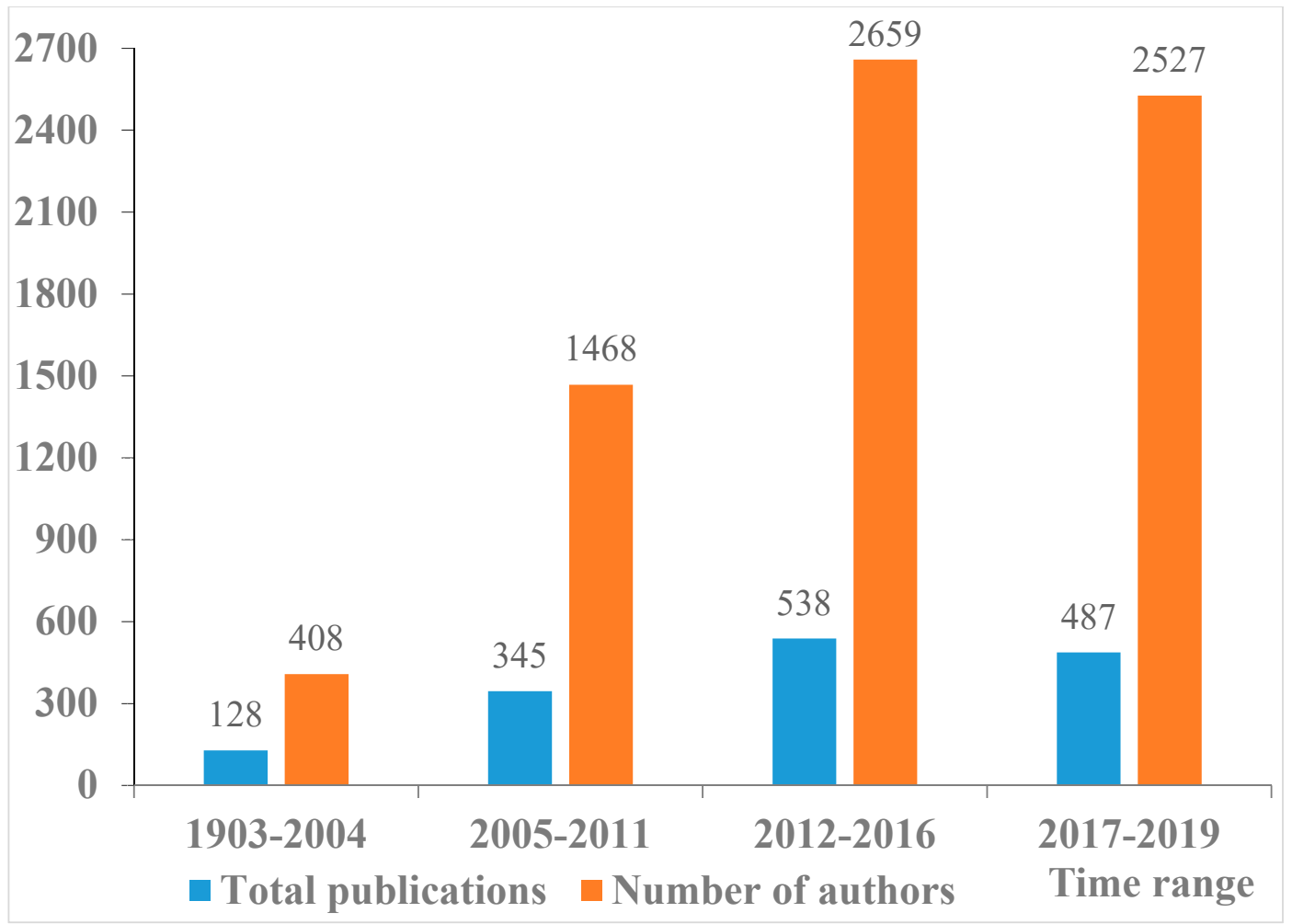

Figure 5. Number of total publications and the number of authors in the research of farmland abandonment in each time range.

The first time period was from 1903 to 2004. At this time period, the total number of publications on farmland abandonment research is 128 , which was the nascent stage of research on farmland abandonment. The second time period was from 2005 to 2011. The total number of publications was 
345 , and the total number of authors was 1468 . The research results and the author's activity slowly increased during this period, which was a slow period in the research of farmland abandonment. Since 2012, research on farmland abandonment has grown steadily and rapidly. During the period of 2012-2016, the research results and the number of authors increased linearly. The number of studies during 2017-2019 fluctuated greatly, with a total of 487 articles and 2527 authors. In general, the research on farmland abandonment started early and developed slowly, developing linearly overall after 2012. It should be noted that in order to the smooth of the data, the best option would be to choose periods spanning only one year. However, in a span of one year, there are not enough data for a good performance of co-word analysis [39]. For this reason, the years are grouped in subperiods of time. Additionally, although it is common to use periods of the same time span, we determined the first subperiod of 100 years (1903-2004) based on the number of documents and the increase in the number of authors. Because in the early days, there were few researchers and publications about farmland abandonment. Therefore, in co-word analysis, in a longitudinal study, it is usual for the first subperiod to be the most long-lasting to get a representative number of published papers. In this way, we provide a good input to the co-word analysis to detect the main themes and the data are divided into four consecutive subperiods.

\subsection{Parameter Selection}

After the literature data set was divided into four periods, the parameter settings of each research period and index needed to be set. First, the analysis unit was set to Word. To improve the comprehensiveness and accuracy of the subject analysis results, a combination of Author's Words and Source's Words was selected. Second, the data reduction threshold for the four time periods was set to $(2,2,3,2)$, the selection matrix form was set to co-occur, and the network reduction threshold was set to $(2,3,3,2)$. Finally, the similarity index of the standardized network was set to Association strength and the clustering algorithm selected was the simple centers algorithm. The maximum value of the network was set to 12 and the minimum value to 3 . The core drawing method was selected, the measurement index was the h-index, and the Jaccard coefficient was selected for the similarity index of the theme evolution map and the theme coverage map.

\section{Analysis of the Theme of Farmland Abandonment from the Perspective of Strategy Map}

\subsection{Results and Analysis of the Theme Evolution from 1903 to 2004}

\subsubsection{Theme Evolution Results}

The study of farmland abandonment was still in its infancy in the first period (1903-2004), and the number of related publications and subject words were relatively small, but the literature played a foundational role for later research. According to the strategic diagram presented in Figure 6a during this period farmland abandonment was focused on three research themes, and the clustering network is shown in Figure $6 \mathrm{~b}-\mathrm{d}$. The landscape-change theme-cluster network includes agricultural-landscape and region and its related literature is very small, with close internal relations and low external relevance, but these articles have been cited very frequently, indicating that an obvious knowledge context was formed in the later period. The theme of grassland is a relatively mature professional topic in the field of farmland abandonment, but it is not a research center and is not important to current development prospects. The forest theme has the characteristics of a weak internal connection and a strong connection with other themes and is a basic theme with great potential for development in the field of farmland abandonment. 


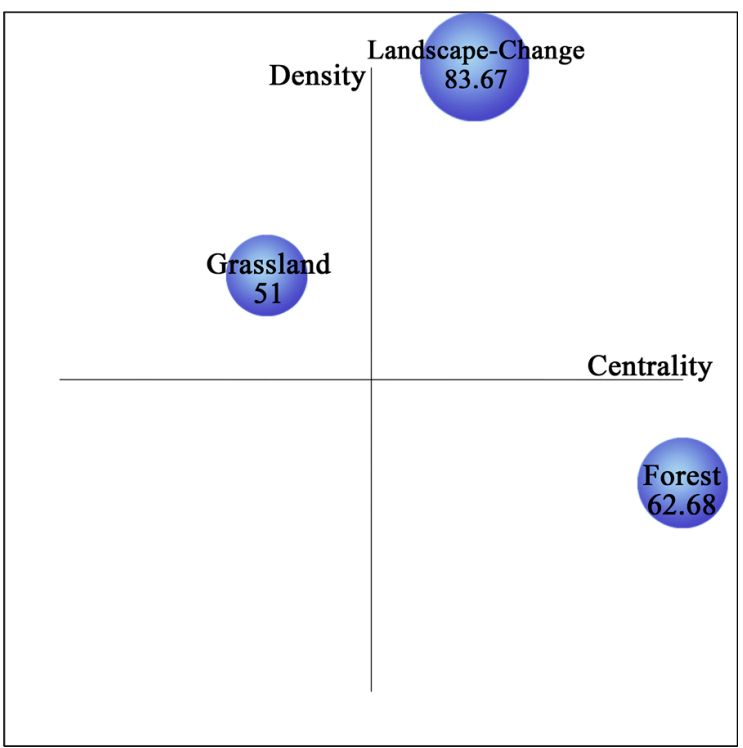

(a)

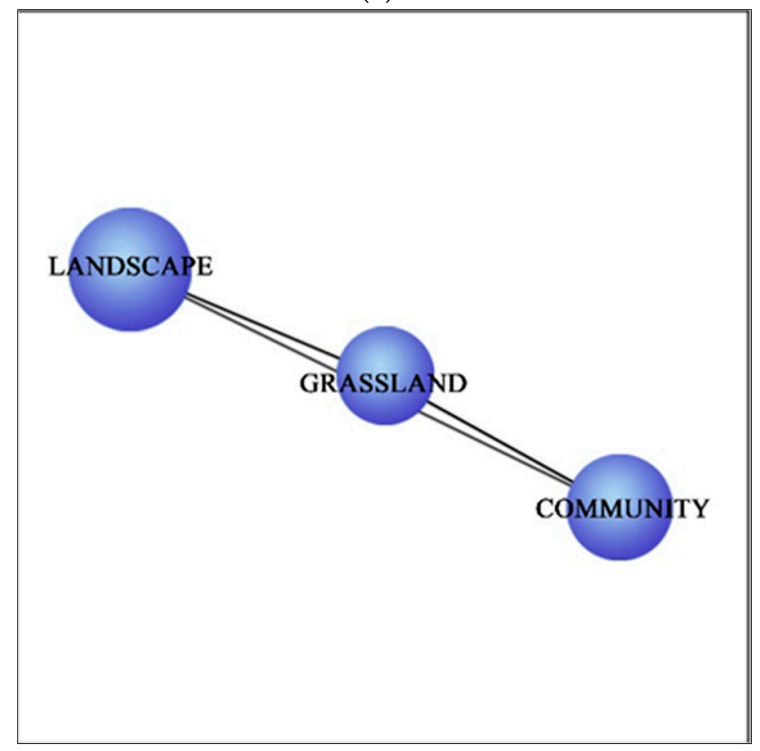

(c)

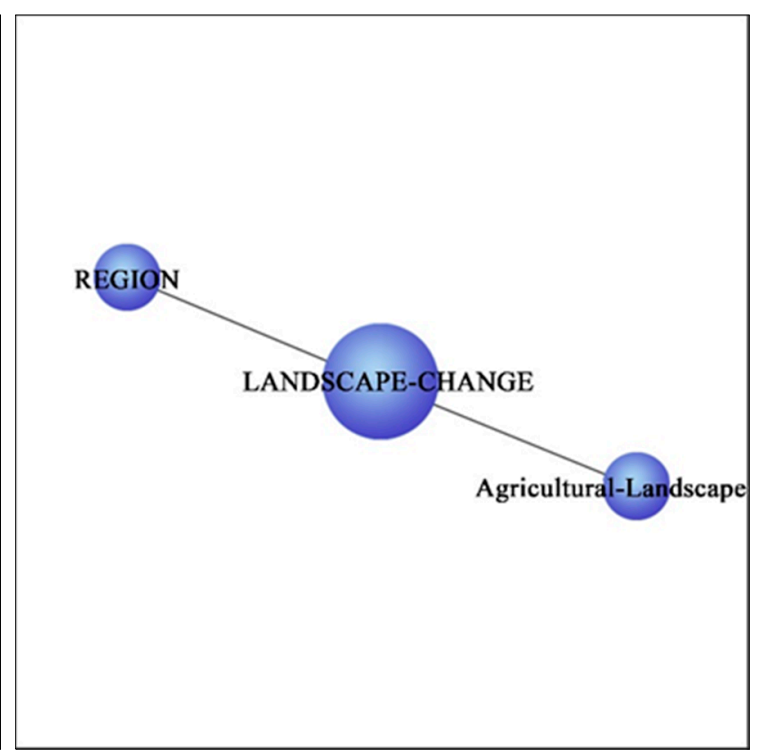

(b)

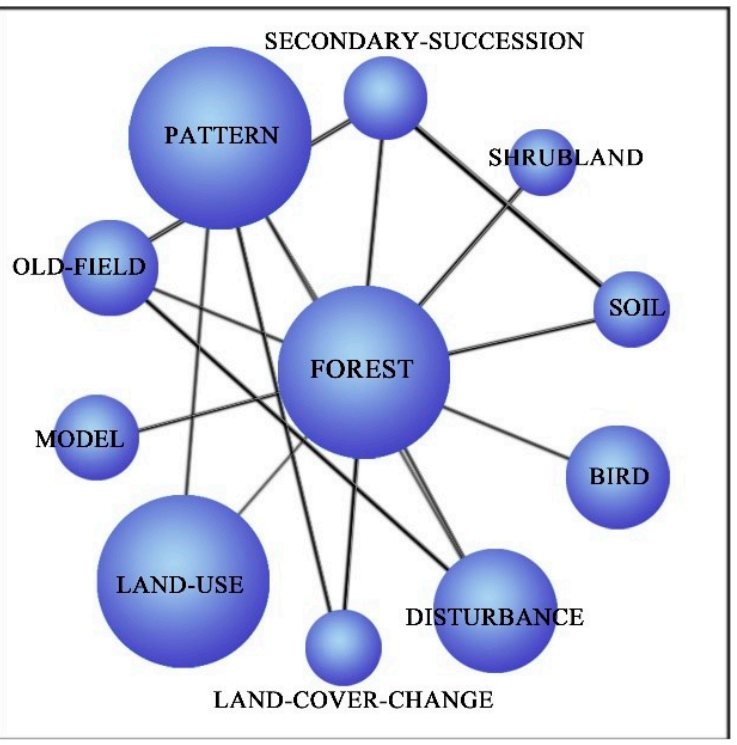

(d)

Figure 6. Farmland abandonment strategic diagram and-cluster network (1903-2004). (a) Strategic diagram for the 1903-2004 period; (b) landscape-change-cluster network map; (c) grassland-cluster network map; (d) forest-cluster network map.

\subsubsection{Theme Evolution Analysis}

Since the beginning of the 20th century, in developed countries, farmland abandonment has attracted the attention of scholars. In 1903, Levy (1903) studied the relationship between British farmers and land abandonment [40]. Wolfanger (1931) believed that soil depletion in the eastern United States was mainly due to overuse by agricultural operators [41]. Driven by the policy of obtaining new high-yield farmland at low cost during the large-scale development of the western region, the plundered land was returned to nature and farmland abandonment caused by soil degradation has become a typical social phenomenon [41]. However, after decades of stagnation in related research, after the 1980s, the abandonment of farmland again attracted scholars' attention. landscape change after desolation is a long, continuous process, but the traditional cultural landscape in Europe is undergoing a huge transformation, and a large number of new landscape types have appeared [42]. Due to social, economic and technological changes, human activities have played a 
decisive role in shaping new natural landscapes, especially in mountainous rural landscapes [43]. In a purely agricultural society, traditional human activities are limited by geography and technology, and they cannot be separated from the scope of community activities formed by the clan system. Therefore, the landscape pattern generally remains in a state in which humans can perform stable production activities after entering the area. However, in the second half of the twentieth century, large-scale landscape changes were very rapid and with the general trend of European farmland abandonment, traditional agricultural landscapes, especially land-use changes driven by political forces [44], have been continuously changing [23]. After World War II, landscape changes were mainly reflected in the expansion of agricultural landscapes, and the focus was on food production. To increase food production, government policies tend to continue providing farmers with economic subsidies and aiming to achieve agricultural intensification by improving infrastructure and increasing technology investment [45]. However, the land use trajectory has gradually moved towards two extremes, namely, agricultural intensification and farmland abandonment. While agricultural intensification has changed habitats with high biologic value created by traditional agricultural practices, it has also triggered many landscape changes. For example, large-scale farmland [45], low-productivity farmland abandonment, seminatural grassland abandonment [46,47] and terraced agricultural landscape abandonment [30]. Although landscape change has been a less visible theme in later studies of farmland abandonment, developed countries have performed much research on landscape changes caused by farmland abandonment, and the results have formed a knowledge context that provides a reference for similar research in developing countries.

Although the grassland theme is not a research focus in the field of farmland abandonment, the impact of grassland abandonment on landscape change and biodiversity is extremely important. In the 1930s and 1940s, large-scale grassland reclamation was carried out in Europe and Asia, land was continuously depleted in the subsequent land use process, and the grassland deforestation rate reached its peak after World War II. By studying the four publications related to the grassland theme, it was found that the predicament faced by grassland ecosystems mainly comes from farmland abandonment [48] and secondary succession is widespread on abandoned farmland. For example, Laiolo et al. (2004) assessed the impact of pasture depletion on the structure and diversity of alpine bird communities. The study found that the landscape change of mountain grassland abandonment is mainly reflected in grassland gradually becoming shrubs and eventually forests, and the decrease in agricultural and animal husbandry activities and pasture abandonment have increased the number of species and the bird diversity during natural succession [49].

Since the middle of the 20th century, the abandonment of farmland and the subsequent natural restoration of forests have been widespread throughout Europe [50-52]. The main content of this field of research includes land cover changes [53], model simulations [54,55], evolution patterns of soil-vegetation patterns [56], spatial aggregation of plant communities [57], biomass estimation [58] and the impact of land use on forest cover [59]. Because the forest theme contains extremely rich content and evolved into multiple themes in the later period, later studies of farmland abandonment are mostly based on this theme. This also shows that the ecological consequences of farmland abandonment have long-term effects, especially the secondary succession process of vegetation after abandonment.

\subsection{Results and Analysis of the Theme Evolution from 2005 to 2011}

\subsubsection{Theme Evolution Results}

In the second period (2005-2011), the farmland abandonment research pivots on four themes (see Figure 7a-of which three major themes can be identified (motor plus basic themes): pattern, landscape and land-use-change. Moreover, Figure $7 \mathrm{~b}-\mathrm{e}$ shows the-cluster network of pattern, landscape, disturbance and land-use-change. The pattern theme-cluster network includes abandoned-field, area, cultural-landscape, environment, fire, forest-fire, index, landscape-change, landscape-pattern, mediterranean-landscape. The pattern theme evolved from the previous landscape-change theme 
by absorbing part of the forest theme, but there are very few topic words shared with the previous period, and more new research topics appear in this period. The landscape theme-cluster network includes bird, bird-community, community, cover-change, land-cover-change, model, mountain-area, old-field, policy, scale, scenario. The landscape theme evolved from part of the previous forest and grassland theme, there were many topic words shared with the previous period, and overall research interest continued to rise. The disturbance theme cluster contains plant and land-use, which absorb the content of the previous forest theme. Research on the disturbance theme has the lowest popularity and influence, mature development, and low correlation with other topics and is a stable and specialized theme. The land-use-change theme-cluster network includes calcareous-grassland, transition, soil, population, impact, forest-transition, forest, ecosystem, cropland and climate-change, which evolved from part of the previous forest theme. This cluster attracted much attention and influence and was an emerging theme in the evolution of farmland abandonment field.

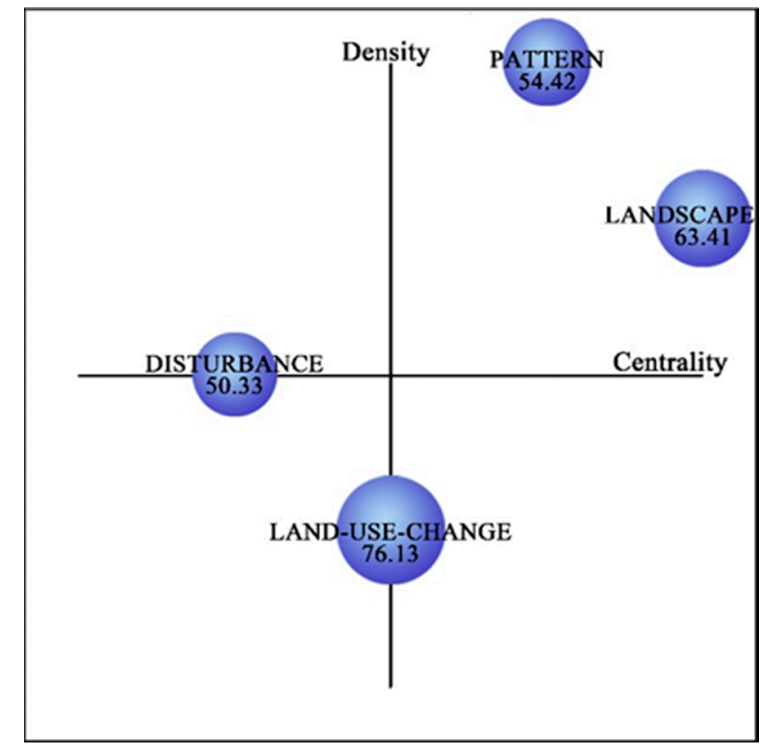

(a)

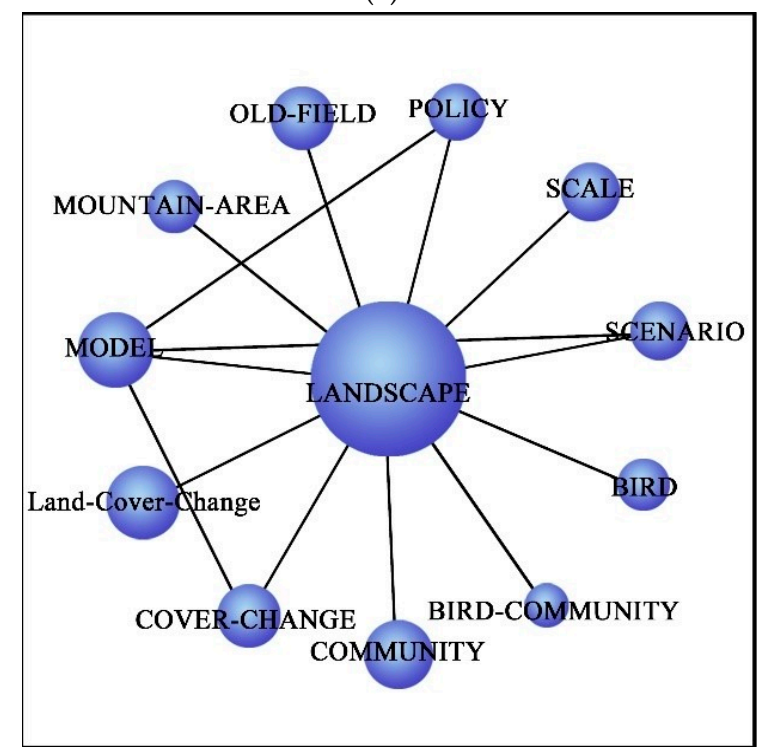

(c)

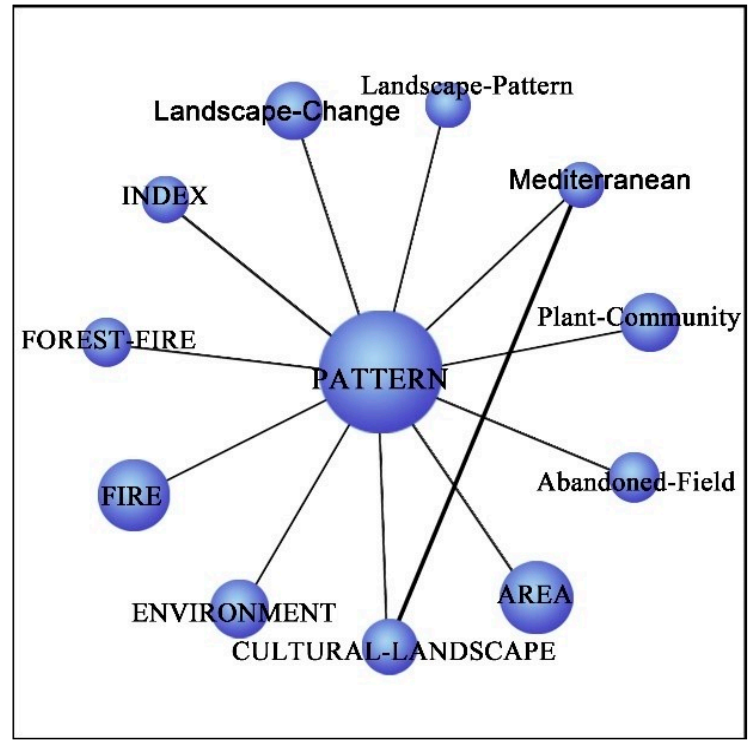

(b)

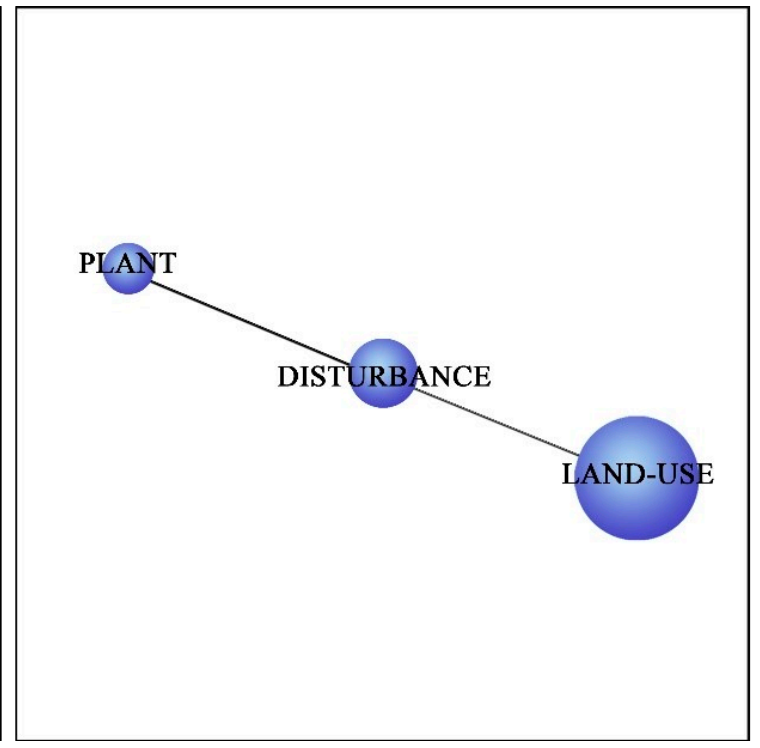

(d)

Figure 7. Cont. 


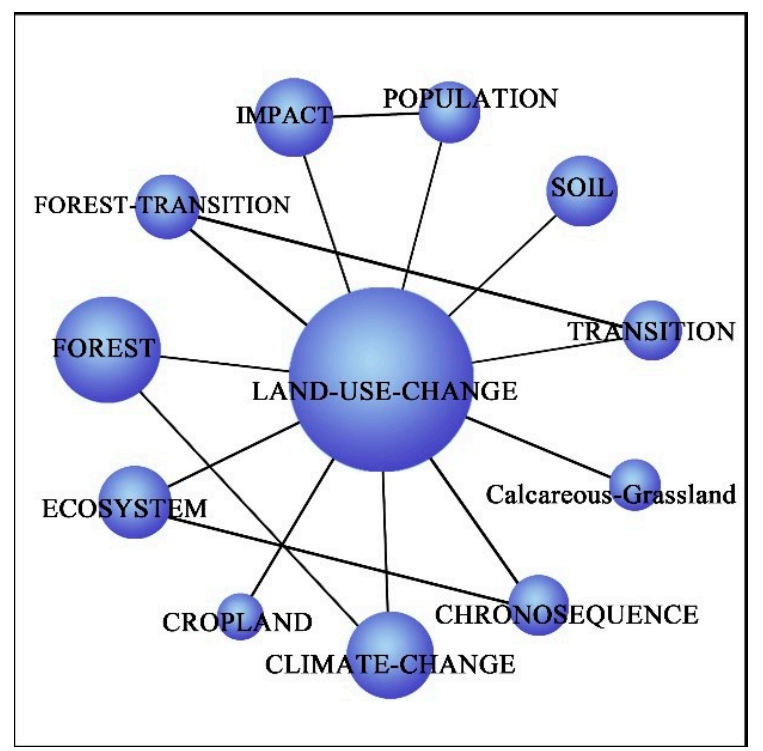

$(\mathbf{e})$

Figure 7. Farmland abandonment strategic diagram and-cluster network (2005-2011). (a) Strategic diagram for the 2005-2011 period; (b) pattern-cluster network map; (c) landscape-cluster network map; (d) disturbance-cluster network map; (e) land-use-change-cluster network map.

\subsubsection{Theme Evolution Analysis}

The most-cited literature in the pattern theme mainly appeared in the years 2008, 2009 and 2011. In the Mediterranean region, the study of fire, soil erosion and land degradation caused by the evolution of natural resources such as soil and vegetation after farmland abandonment attracted much attention from scholars during this period $[60,61]$. The impact of farmland abandonment and subsequent forest regeneration as one of the main processes of land use/land cover change on its environmental and socioeconomic consequences was also extensively studied during this period [52]. For example, agricultural landscape patterns, farmland abandonment and development processes are considered to be the main factors affecting forest fires in Spain [62]. Landscape homogeneity and grassland invasion after farmland abandonment increase the probability of fires [63,64]. Different land use methods (cultivation, short-term depletion and long-term depletion) have different degrees of impact on the soil erosion of terraces. The original terraces are no longer maintained, which makes the soil erosion process on the terraces more active $[65,66]$. The landscape change caused by farmland abandonment is mainly reflected in the regeneration and expansion of vegetation [66], and a large number of forest birds have benefited from forest spread after farmland abandonment [67].

It can be seen from the original literature that the landscape clustering pays the most attention to revealing the abandonment ratio and spatial pattern of farmland [68], the regeneration pattern of natural forests [4], the dynamic processes of land use change and vegetation regeneration [69], the impact of abandonment and fire on biodiversity [70] and the change in landscape composition and structure by using models [71]. For example, Verburg et al. (2009) used a dynamic model of land use to illustrate the interaction between changes in farmland demand and natural vegetation regeneration processes, and their findings help in determining future dynamic changes in land use and landscapes in Europe [69]. Kuemmerle et al. (2008) studied and compared the farmland abandonment rate and spatial pattern of Eastern European countries in the post-socialist period through the support vector machines (SVM) model and found that the farmland abandonment rate and spatial pattern of different countries were different, which was related to the form of land ownership, land reform policies and the size of the rural population [72].

Disturbance has a close correlation with the internal node plant theme and is more related to ecosystem restoration after farmland abandonment. For example, Baur et al. (2006) studied the impact 
of farmland abandonment on the biodiversity of subalpine hay meadows and evaluated the species richness and abundance of meadows in a continuous succession process [73]. The results show that the subalpine grassland succession stages have high protection value for Transylvanian indigenous biodiversity. Flinn et al. (2005) believes that disturbance may lead to continuous environmental change and continue to affect vegetation restoration, so a clear understanding of the interaction mechanism between disturbance and environment can better assess the consequences of current forest land-use decisions [74].

The important nodes within the land-use-change theme-cluster network are cropland, ecosystem, calcareous-grassland, forest-transition. The study of the literature found that the important node corresponding to abandoned farmland ecological effect research is the largest research hotspot in this period. Land-use change research focuses on forest regeneration [74-76], carbon sequestration [77] and population expansion in abandoned areas [78]. For example, Gehrig-Fasel et al. (2007) analyzed the influencing factors of forest regeneration in the Swiss Alps and the results showed that regardless of whether forest growth or forest line up occurred, farmland abandonment was the most important driving factor [75]. Kuemmerle et al. (2011) studied the impact of post-abandonment land use patterns on carbon flux in western Ukraine and assessed the region's future carbon storage potential [77]. Sirami et al. (2011) believe that the landscape heterogeneity formed in the early days of farmland abandonment is the main factor leading to the expansion of skylark populations in the Mediterranean [78].

\subsection{Results and Analysis of the Theme Evolution from 2012 to 2016}

\subsubsection{Theme Evolution Results}

The study of farmland abandonment grew between 2012 and 2016. The clustering theme during this period is shown in Figure 8. The themes of the cluster in the upper right quadrant are climate-change, pattern and land-use-change. Only 'climate-change' is the new clustering theme, and the overall change of the research theme is small, indicating that the theme of the previous period has developed stable and continues to become a research hotspot. land-use-change theme moved from the lower right quadrant to the upper right quadrant during this time period and became more mature. climate-change evolved from the previous land-use-change theme that absorbed some of the landscape and Disturbance themes. In addition, the clustering themes in the lower left quadrant are landscape and grassland, which shrank to a state of near extinction and were easily absorbed by other themes in the evolution process.

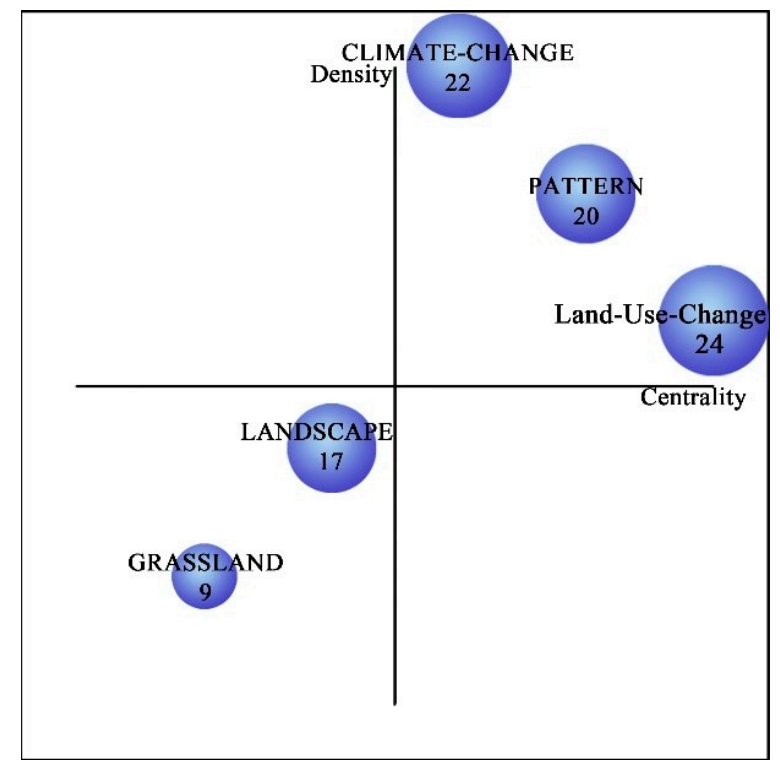

Figure 8. Farmland abandonment strategic diagram (2012-2016). 


\subsubsection{Theme Evolution Analysis}

Compared with the clustering theme in the upper right quadrant, the research on farmland abandonment has expanded from a focus on ecosystem services and vegetation succession effects to research on the driving forces of farmland abandonment. This period mainly focused on the impact of changes in the conditions of farmland abandonment at the macro level. For example, the main driving force of the abandonment of farmland in Eastern Europe was institutional change [79]. After the collapse of the Soviet Union, the collapse of the governance structure of socialist countries led to the widespread abandonment of farmland [80]. However, due to differences in the specific policies and measures among these socialist countries, it is particularly valuable to study the driving factors of farmland abandonment in former socialist countries [81]. The transformation of the land property rights system from public ownership to private ownership is considered to be a major factor in the abandonment of farmland in Eastern Europe, while market-driven economic transformation directly led to widespread farmland abandonment [82]. The reduction or even cancellation of agricultural subsidies and the lack of liberalized markets and clear government policies also contributed to the large-scale abandonment of farmland [81,83]. In addition, changes in natural factors also increased the possibility and adverse consequences of farmland abandonment. For example, Latocha et al. (2016) added climate change factors to the assessment of changes in the spatial distribution of soil erosion rates, and the results show that global climate change outweighs land use changes in affecting soil erosion rates on a large scale [84].

The clustering theme in the lower left quadrant is still more focused on the impact of farmland abandonment on landscape and biodiversity. For example, Navarro and Pereira (2012) believe that farmland abandonment and forest regeneration are conducive to promoting biodiversity and can enhance regional ecological services functions such as carbon sinks, so forest restoration should be promoted in mountain areas [85]. Uchida and Ushimaru (2014) simulated various environmental conditions to reveal the mechanism of biodiversity decline caused by farmland abandonment and intensification [86]. The predicted results showed that farmland abandonment led to changes in the surrounding landscape, and the decrease in biomass and resource diversity led to a decrease in biodiversity. In the biodiversity conservation ecosystem service function, Hinojosa et al. (2016) showed, through a quantitative analysis of abandoned grassland in the southern Alps region of France from 1990 to 2006, that reserving the mountainous half for livestock and maintaining the natural grassland biodiversity of the mountain provides barrier protection, the abandonment of grassland in different landscapes and spatial distributions is uneven, and grassland on hillsides is more likely to be abandoned [87].

\subsection{Results and Analysis of the Theme Evolution from 2017 to 2019}

\subsubsection{Theme Evolution Results}

The clustering theme during 2017-2019 is shown in Figure 9. According to the strategic diagram shown in Figure 9, four major themes can be identified (motor plus basic themes): transition, climate-change, forest, land-use. Among them, the transition theme evolved from absorbing part of the content of all themes in the previous time range and was the most frequently cited theme in this time period, making it a relatively mature and highly researched theme. impact clustering was derived from the climate-change theme, which absorbed part of the pattern theme and belongs to the specialized clustering theme. Both transition and impact were new clustering topics in this time range. Compared with the clustering network graph of the previous period, landscape moved from the lower left quadrant to the upper left quadrant of the segment during this time, becoming a specialized cluster. land-use-change moved from the upper right quadrant to the lower left quadrant of the section during this time and showed loose internal connections and close connections with external themes. 


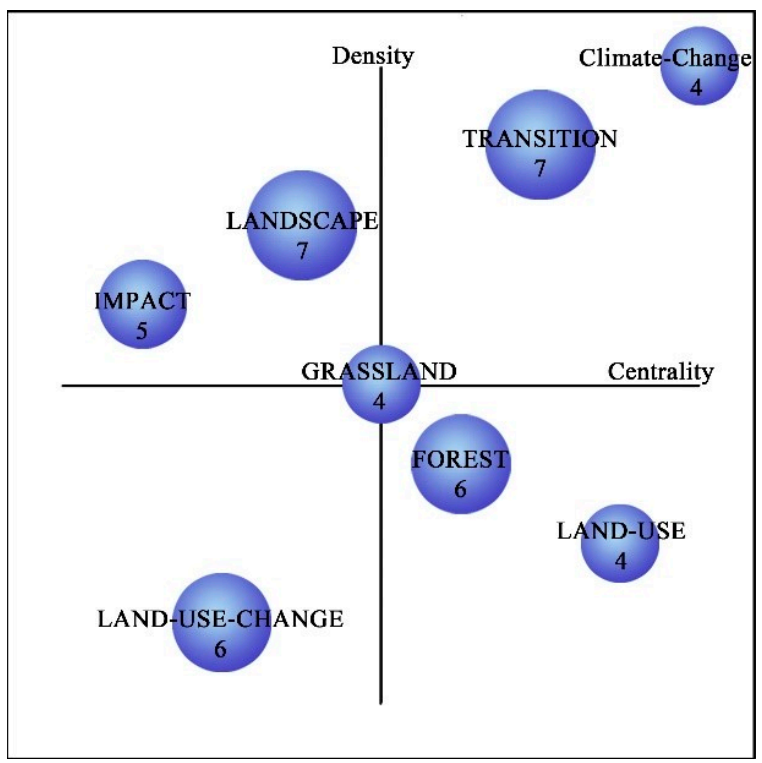

Figure 9. Farmland abandonment strategic diagram (2017-2019).

\subsubsection{Theme Evolution Analysis}

The clustered themes in the upper right quadrant are climate-change and transition. The theme of climate-change deviates more from the origin than the previous period, indicating that the theme's maturity and central position in the research field increased, the research heat and influence were further enhanced and the theme has greater development potential. The clustering network diagram of the new clustering topic "transition" has a total of 11 nodes (see Figure 10) and the "households" scale is a new research direction in the field of farmland abandonment.
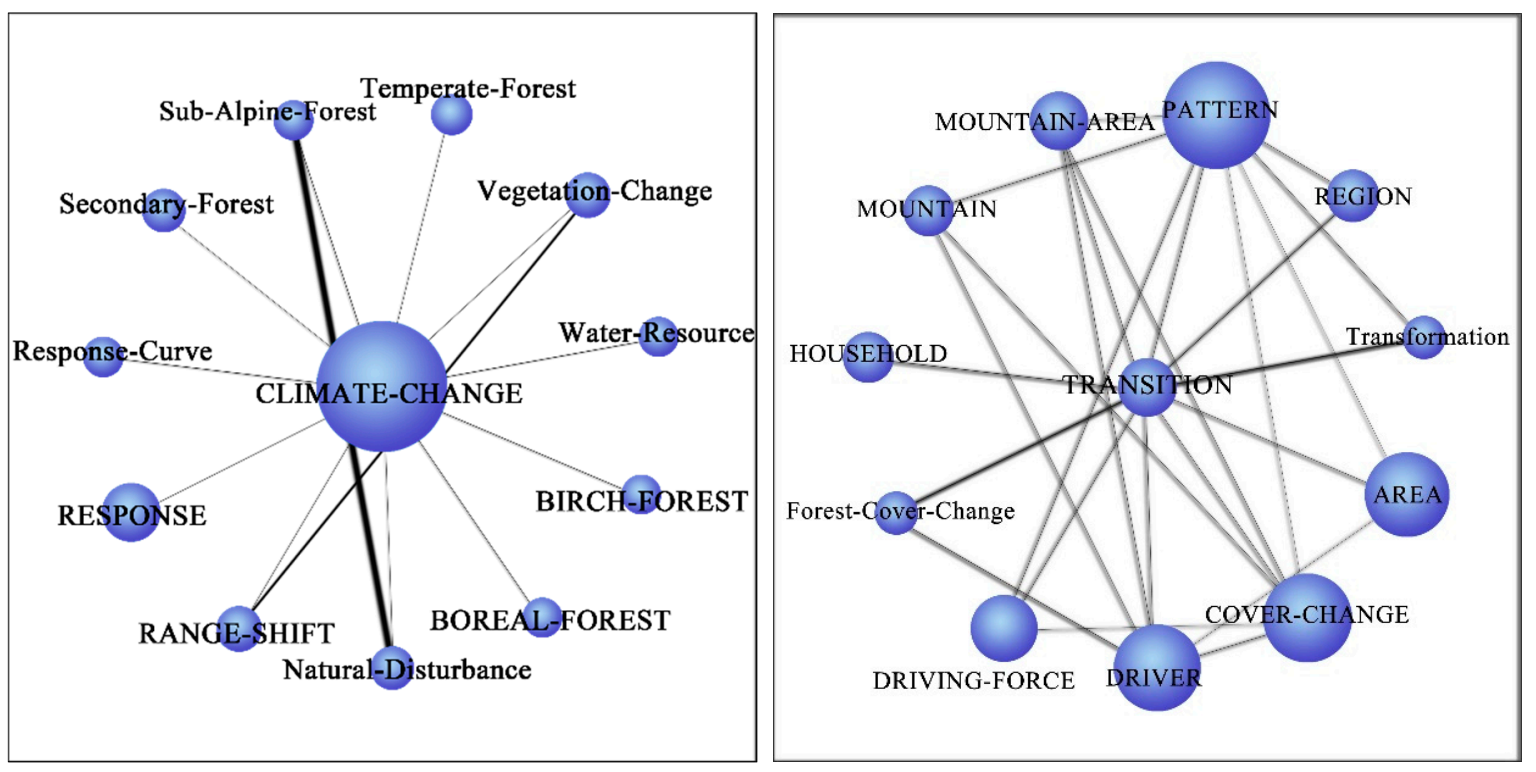

Figure 10. Climate-change and transition-cluster network map.

The clustered topics in the upper left quadrant are landscape and impact. Impact has strong mutual citations with the nodes of "cost", "rural-area" and "marginal-land" (see Figure 11). With the increasing opportunity cost of non-agricultural employment, labor migration in rural areas has led to a widespread increase in farmland abandonment in marginal areas and has caused widespread concern among scholars, especially in developing countries such as China. 


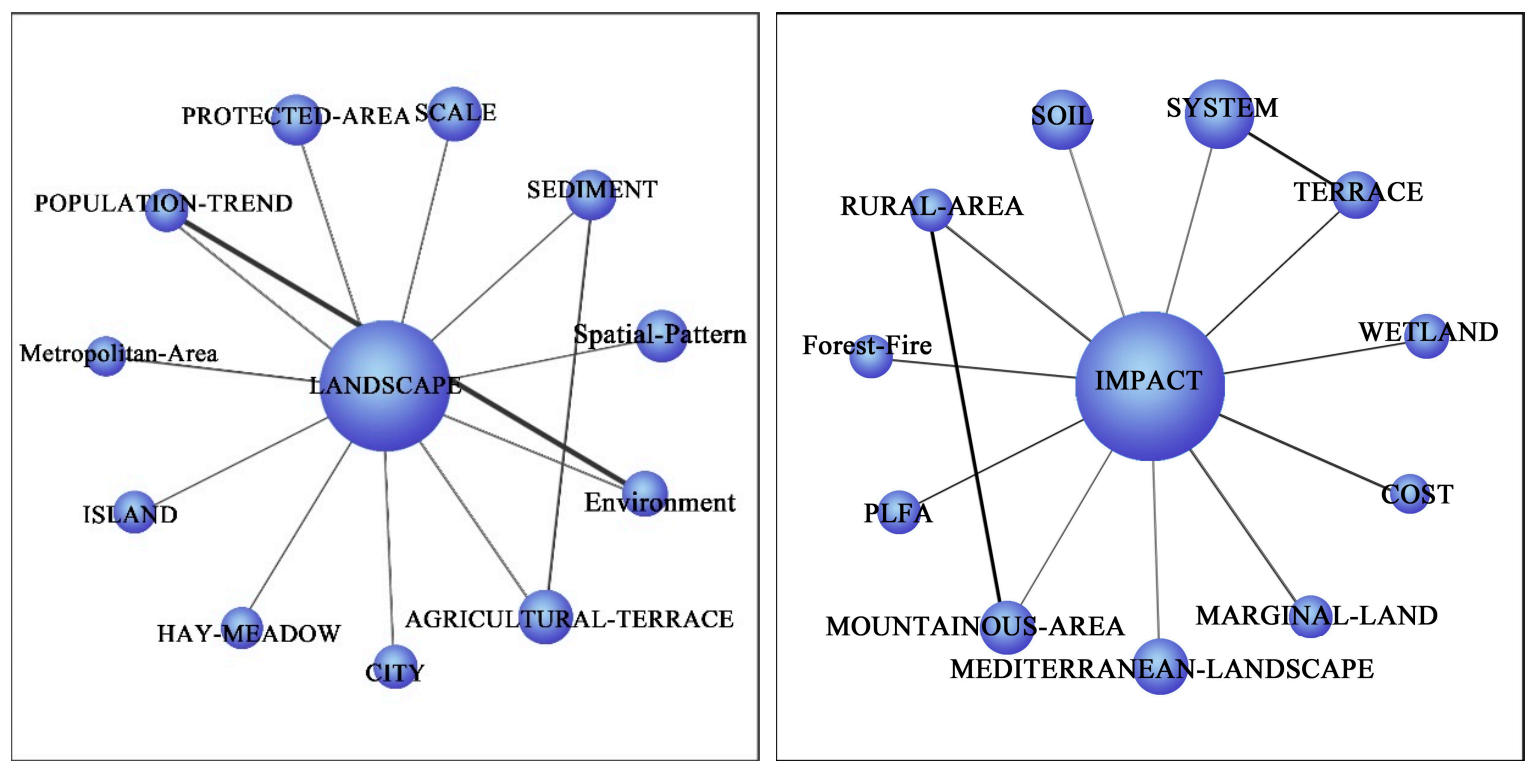

Figure 11. Landscape and impact-cluster network map.

In the related literature, the research on the impact of socioeconomic factors on farmland abandonment is mainly focused on regional and farmer scales. At the regional scale, many Chinese scholars have constructed specific indicators to characterize socioeconomic conditions and used them to reveal the impact mechanism of farmland abandonment. For example, these indicators include the opportunity costs of farming, nonagricultural income share proportion, the proportion of rural labor, employment, urbanization rate, land circulation rate and agricultural subsidies, including the opportunity cost of farming, nonfarm income share, proportion of nonagricultural employment, urbanization rate and significantly positive promoting effect between abandoned farmland, farmer income, proportion of rural labor force, land circulation rate and agricultural subsidies to slow down the role of abandoned farmland [1,88-90]. Studies on the factors affecting farmland abandonment mostly focus on the characteristics of farm households, such as the number of households, the proportion of the agricultural labor force, the average age of the family, education levels, the family dependency ratio and the degree of concurrent employment $[1,89,91,92]$. The higher the average age of the family, the dependency ratio and the degree of part-time employment, the greater is the possibility of abandoning farmland-and the larger the number of families and the proportion of the family's agricultural labor are, the less likely it is that farmland will be abandoned.

The clustering topics in the lower left quadrant are land-use-change and grassland. Although the themes in this quadrant shrank and came close to being eliminated, there are also some emerging research directions in this quadrant. The land-use-change and grassland clustering networks have 11 and 6 nodes, respectively (see Figure 12). The legacy effect and the effect of the population are new research hotspots in the field of farmland abandonment. For example, Sklenicka et al. (2017) studied the development process of the rural historical landscape in the Czech Republic from 1996 to 2016 and explored the main factors of its existence or extinction [93]. The results showed that the main factors affecting the retention of high-value landscapes were land-use planning measures and the security of land-use rights. Blair et al. (2018) studied the impact of farmland abandonment and farmer household demographics in South Africa from 1950 to 2010. The results show that farmers who were actively engaged in agricultural production in the past believe that the reason for the abandoned of farmland is the lack of agricultural irrigation facilities and the fact that modern young people are unwilling to engage in excessively heavy and economically inefficient agricultural production activities [94]. 

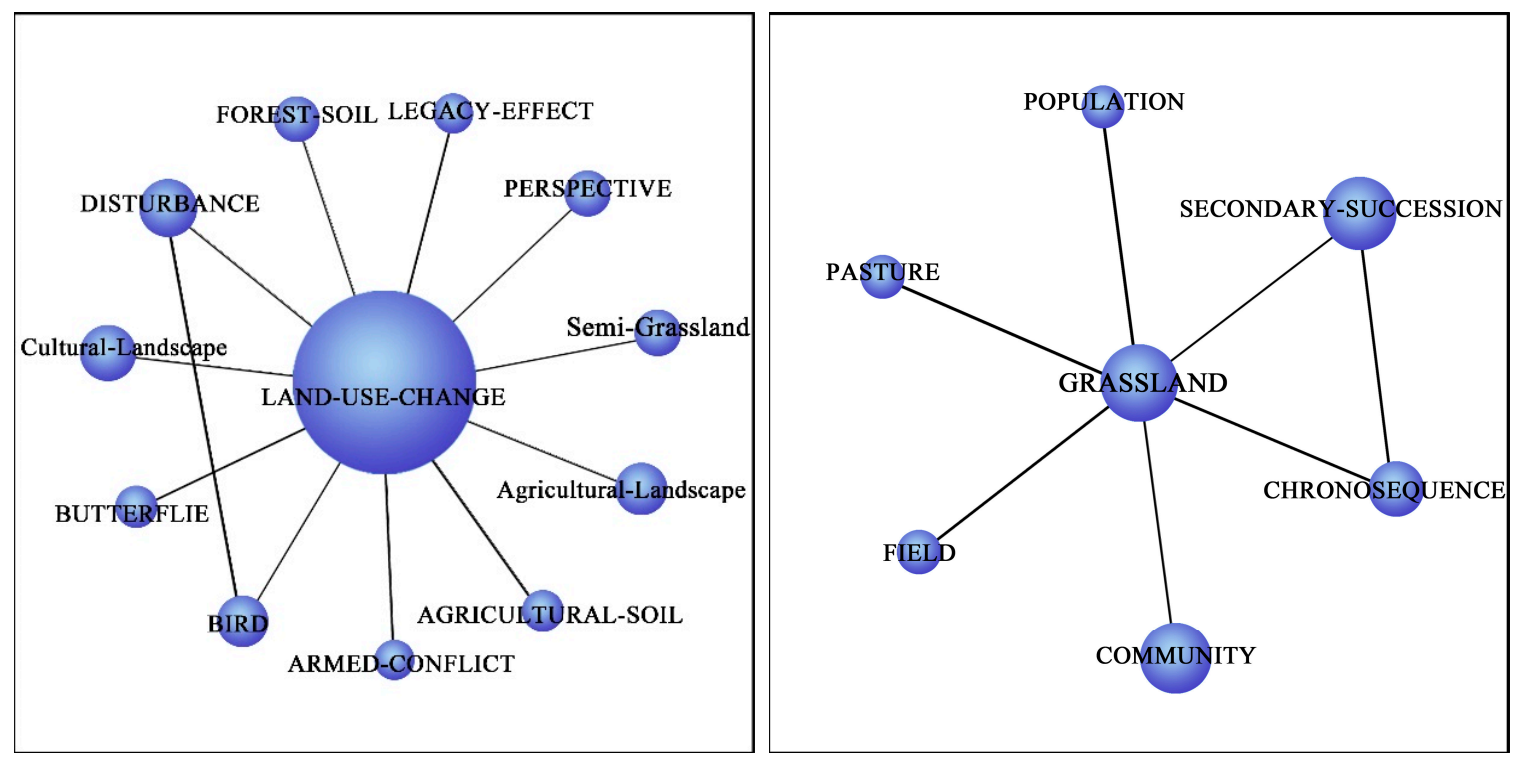

Figure 12. Land-use-change and grassland-cluster network map.

The clustering topics in the lower right quadrant are land-use and forest. The forest theme has strong mutual citations with the nodes of bird-community and species-distribution (see Figure 13), indicating that species distribution and bird communities have attracted widespread attention in the field of farmland abandonment. For example, Estruch et al. (2018) evaluated changes in the carbon balance of plant communities after the abandonment of farmland in arid environments in southern Spain [95]. The results indicate that the restoration of dry plant communities after farmland abandonment may strengthen long-term carbon sinks and make a significant contribution to the global carbon balance. Deguchi et al. (2017) studied the impact of farmland abandonment on yellow-throated magpies in the hilly areas of northern Japan [96]. The results showed that although farmland abandonment provided habitat for birds, abandonment had no effect on the species richness of yellow-throated salamanders, and the forest edge density and landslide position had a positive effect on the species richness of yellow-throated salamanders.
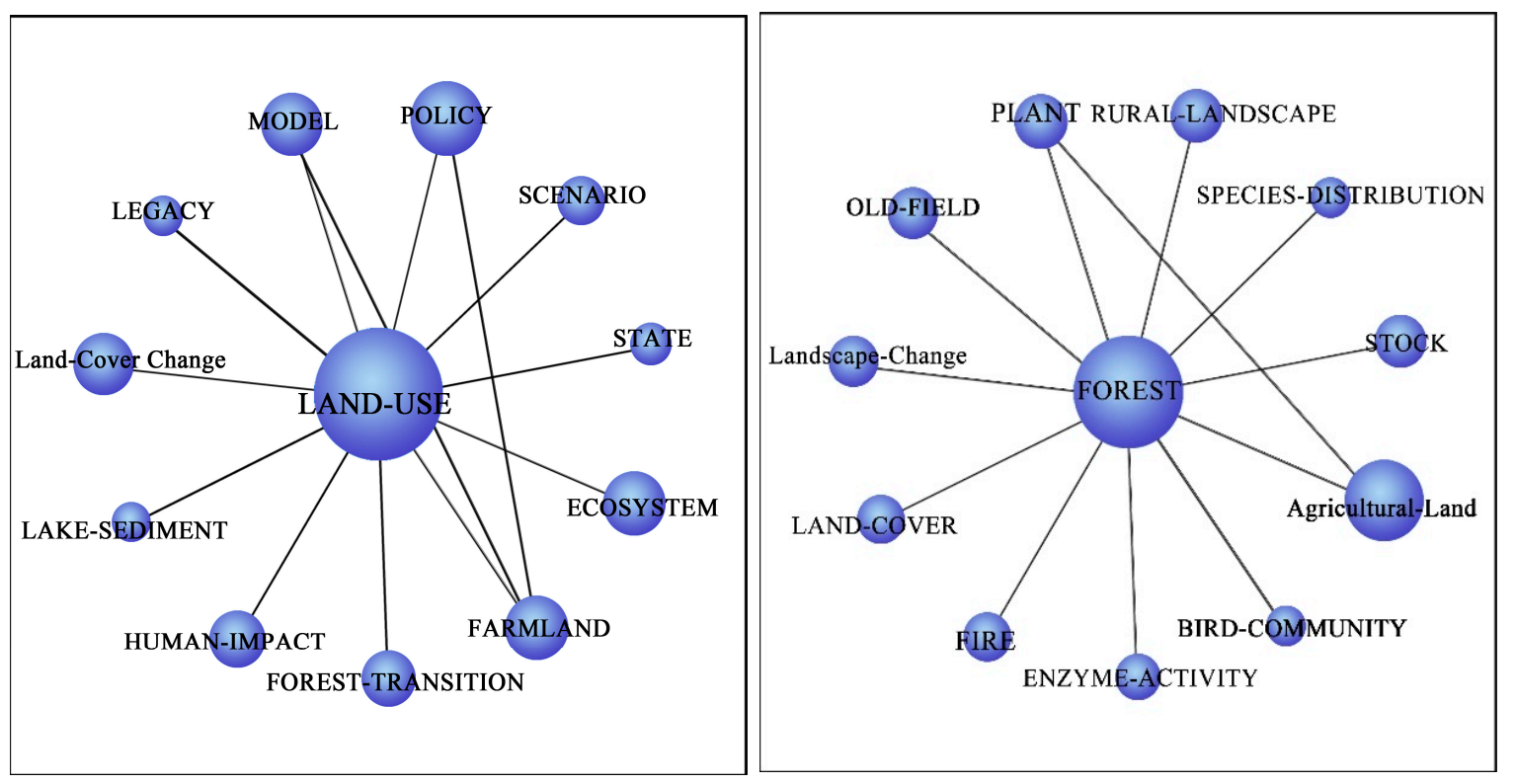

Figure 13. Land-use and forest-cluster network map. 


\section{Analysis of the Dynamic Evolution of Farmland Abandonment from a Data Stream Perspective}

The theme's data flow, increase and decrease in data, and data inflow and outflow reflect the evolution of the theme in the study time interval, reveal the development and change of the theme over time and show the path of the theme evolution in the field of farmland abandonment. Overlapping maps and evolution maps can visually show the data flow between research time intervals and topics. After processing the keywords in the farmland abandonment documentation dataset from 1900 to 2019, a topic coverage map and evolution map represented by the keywords were constructed, and the evolution of research topics in the field of agricultural abandonment was analyzed and tracked from a data flow perspective.

\subsection{Dynamic Analysis of the Evolution of the Coverage of Farmland Abandonment Research Topics}

Figure 14 is a theme coverage map of the four stages of the farmland abandonment field, which clearly reflects the emergence and disappearance of the themes in the farmland abandonment field. The four circles in figure represent the four time periods of farmland abandonment research, and the number of subjects is, chronologically, 136, 254, 284 and 266, showing a steady growth trend. From 1903 to 2004, there were a total of 136 research topics, and 109 topics passed to the next time period. The stability index of the research time period was 0.39 , indicating that the research on farmland abandonment in 1903-2004 was in the initial development stage. In the 2005-2011 research period, 109 themes from the previous research period were used, and 145 new topics emerged in this time period. Although the number of newly added subjects in this period is the largest of all time periods, the corresponding number of studies indicates that the area of farmland abandonment research was still in a slow period. From the perspective of stability, the stability indices between research topics in the three time periods are, chronologically, $0.39,0.63$ and 0.65 , and the stability index continues to increase, indicating that researchers have paid more attention to the same research topics across time and that the research continuity is strong. This also indicates that the research content and topics in the field of farmland abandonment are stable and the discipline maturity is high; on the other hand, it also indicates that the research topics are similar and tend to be solidified, so the research on farmland abandonment needs to be supplemented with more new research topics.

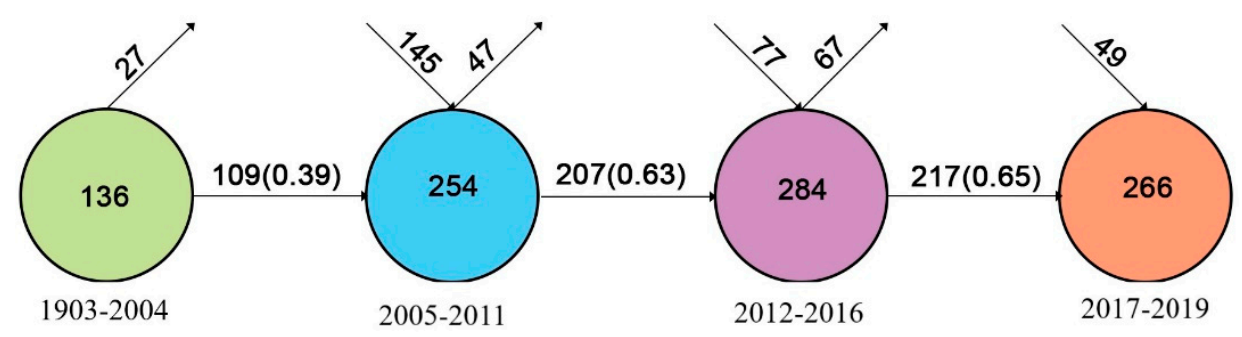

Figure 14. Overlapping-items graph of farmland abandonment research field from 1900 to 2019.

\subsection{Analysis of the Dynamic Evolution Path of the Research Topics on Farmland Abandonment}

The theme evolution diagram shows the evolution trend of each theme in the four research time periods in the form of a data stream, which can help in analyzing and tracking the dynamic changes in the field of farmland abandonment. In Figure 15, the diagrams of the theme evolution in the field of abandoned farmland visually identify the themes that appeared in each time period. For example, the themes that have appeared (landscape), the themes that have disappeared (landscape-change, Disturbance), and the themes that appeared in the last stage (transition, impact). In general, the theme evolution graph shows that each column of nodes tends to become larger, and the data flow between nodes becomes increasingly complex, reflecting the international attention paid to research on farmland abandonment, constantly giving rise to new research topics. As shown in the topic evolution diagram, the size of the topic node and the data flow between topics were examined, and five obvious topic evolution paths in three research directions were identified in the field of farmland abandonment. 


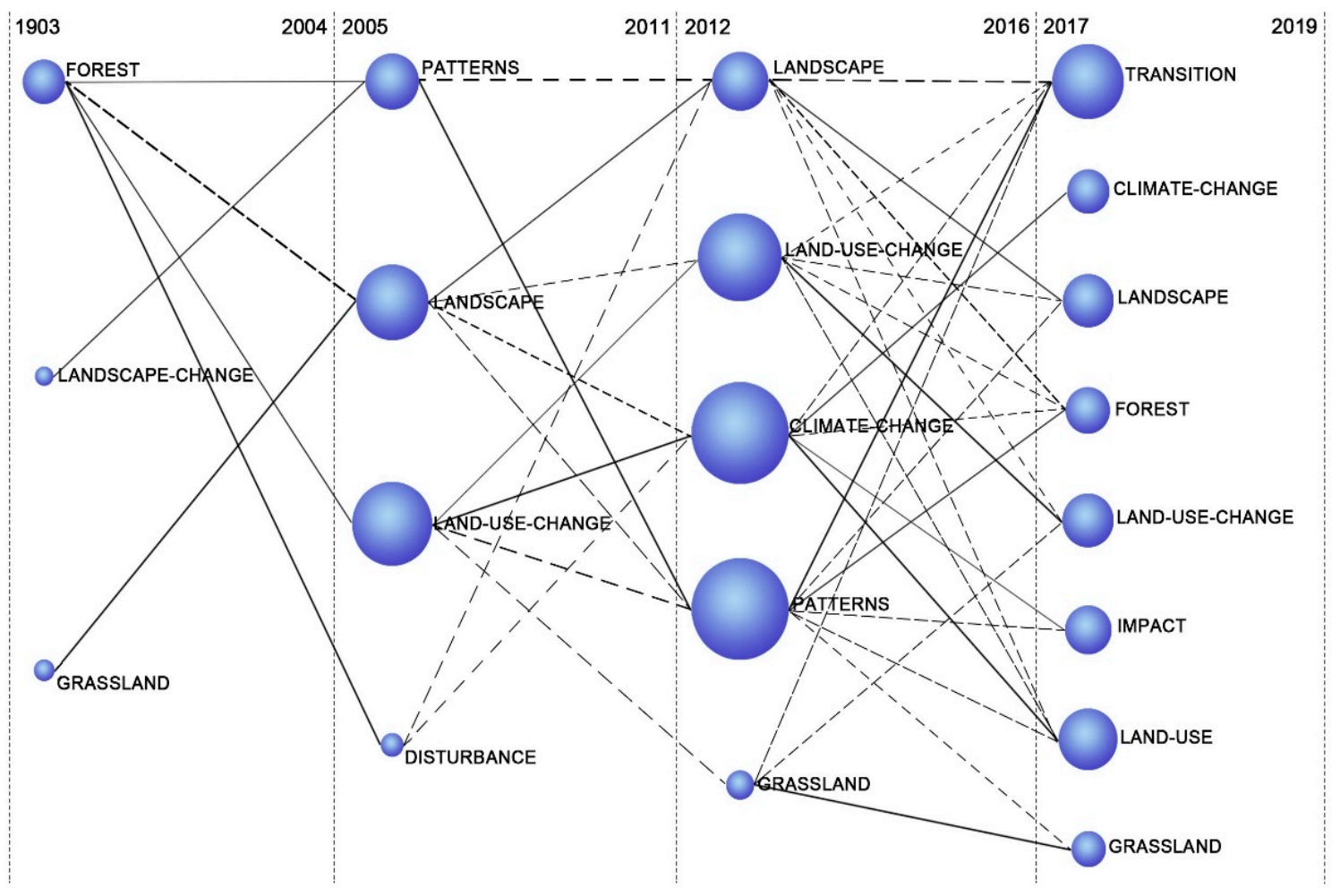

Figure 15. Thematic evolution of the farmland abandonment research field (1900-2019).

(1) Studies on landscape and eco-environmental effects of farmland abandonment. (1) forest $\rightarrow$ landscape, pattern $\rightarrow$ landscape $\rightarrow$ forest, landscape; (2) grassland $\rightarrow$ landscape $\rightarrow$ pattern $\rightarrow$ transition, forest, grassland; and (3) landscape-change $\rightarrow$ pattern $\rightarrow$ transition, forest. landscape and eco-environmental effects are the main paths in the field of farmland abandonment. From the evolution path of the landscape and eco-environment effects literature from 1903 to 2019, it can be seen that the expansion of traditional agriculture and forestry has changed the natural heterogeneous landscape in rural mountain areas. Due to socioeconomic development, agriculture has expanded from intensive to intensified and farmland abandonment has occurred in many places. As a result, mountain landscapes have been gradually occupied by shrubs and woodlands during natural succession processes $[23,97,98]$, and landscapes around the world have again undergone large-scale changes [85]. The research on landscape and eco-environmental effects in the field of farmland abandonment mainly focuses on the following aspects.

(a) impact of farmland abandonment on biodiversity. The controversy over the impact of farmland abandonment on biodiversity is very intense [3]. On one hand, negative perspectives on the consequences of farmland abandonment account for a relatively large proportion [99,100]. Human activities have intervened less in extensively managed farmland, but these farmlands are also easily abandoned, especially in habitats with high natural value and rich species diversity [101]. After this kind of abandonment of farmland, natural succession of the ecosystem and biologic community and habitat destruction, some species disappear, and protection and cultural heritage have high value in traditional agricultural landscape degradation [19], resulting in a reduction in genetic diversity of wild species and crop varieties [102,103]. On the other hand, from the perspective of ecosystem service functions, farmland abandonment may have a positive effect on biodiversity [85]. The forest expansion caused by the abandonment of farmland will benefit the growth of birds and animals, and the restoration of the forest increases the land area suitable for the survival of forest species.

(b) impact of farmland abandonment on carbon sequestration. It is generally believed that one of the benefits of vegetation regeneration is carbon storage and that natural vegetation recovery after farmland abandonment is a carbon storage process [104]. forest regeneration on abandoned land 
can increase soil carbon storage [105], so forest restoration after farmland abandonment has a large carbon sink effect, which is conducive to improving the global ecological environment and limiting the greenhouse effect. For example, empirical studies have found that carbon reserves in farmland after depletion are significantly higher than those in actively managed carbon pools [106]. It should be noted that the degree of recovery of carbon reserves depends on the time after depletion, and the recovery process usually follows a nonlinear trajectory [107].

(c) impact of farmland abandonment on the surface environment. Due to the large difference in natural vegetation restoration time caused by the abandonment of farmland in different climate zones, the succession rate of vegetation has a greater impact on soil. The timely restoration of vegetation will increase the soil infiltration rate, reduce surface runoff, effectively reduce soil erosion and improve soil fertility $[108,109]$. However, in semiarid areas, due to the slower recovery of vegetation, surface runoff and groundwater flow increase after farmland abandonment, which significantly increased soil erosion and land degradation on sloped farmland [17].

It is worth noting that the research on the effects of farmland abandonment mostly focuses on the landscape and ecological environment, but there are few studies on the socioeconomic benefits of farmland abandonment, especially in quantitative assessments. Compared with developed countries, developing countries have mostly explored the impact on farmland abandonment from socioeconomic and policy aspects. Especially in China, farmland abandonment is one of the most important forms of current land use and cover changes. Therefore, we should not only pay attention to the effects and impacts of abandonment, but also focus on the interaction between farmland abandonment and the ecological environment and on socioeconomic development across a long period of time. Moreover, the results of the research on the effects of farmland abandonment are used as the basis for policy makers, and to a large extent, these results affect whether policy formulations promote desertion to restore the ecological environment or prevent desertion to protect farmland. Therefore, a key component of China's research on farmland abandonment is the evaluation of the eco-environmental effects of farmland abandonment and its regional differences so that the design of farmland abandonment response policies can be differentiated and more targeted.

(2) Research on land use change and ecosystem processes. (1) land-use-change $\rightarrow$ climate-change $\rightarrow$ Land-Use; (2) forest $\rightarrow$ land-use-change $\rightarrow$ Land-Use, land-use-change. Farmland abandonment is one of the important manifestations of land use change. During the evolution of the theme of farmland abandonment, the research interest in land-use change has been unabated, and its nodes gradually increased through the research time periods. To date, abandoned farmland has become an important research direction in the field of land use and land cover change. For example, from the assessment of the impact of farmland abandonment on forest fire [62], biodiversity [110,111], carbon emissions [112], soil nutrients [113], soil erosion [84], etc., to the simulation of future land use change trajectories and the tradeoff between the social economy and ecological environment system.

(3) Studies on the influencing factors of farmland abandonment. (1) forest $\rightarrow$ Disturbance $\rightarrow$ climate-change $\rightarrow$ impact; (2) landscape-change $\rightarrow$ pattern $\rightarrow$ impact. Although the clustering and splitting phenomenon of influencing factors research is not obvious, it has a strong internal correlation with clustering topics, which is an important research topic in the field of farmland abandonment. From the perspective of the theme's dynamic evolution path, in the early days, scholars paid less attention to the driving factors of farmland abandonment, mainly focusing on farmland abandonment caused by natural conditions. The causes of farmland abandonment in various countries can be attributed to unfavorable environmental conditions (for example, higher altitudes, larger slopes, poor soils, poor farmland consolidation, low average yields of cultivated land, severe soil erosion, land desertification, salinization, rocky desertification) and remote agricultural areas $[23,81,114]$. Over time, the proportion of research on socioeconomic factors of farmland abandonment has gradually increased. The root cause of the large-scale abandonment of farmland experienced in the process of urbanization and industrialization in developed countries lies in the marginalization of farmland caused by the increase in the opportunity cost of farming [115]. For example, the reduction of 
agricultural subsidies, advances in agricultural technology, the rising prices of agricultural resources, changes in agricultural product prices, and the implementation of ecological protection policies have been driving factors of farmland abandonment [3]. Nowadays, large-scale farmland abandonment phenomenon is gradually appearing in developing countries, so the research on the influencing factors of farmland abandonment will be further enhanced in the future.

Although there are various methods for the study of farmland abandonment, especially the use of remote sensing technology to map and monitor farmland abandonment on a large scale and across a large space [116-119]. However, the study of farmland abandonment in China lacks regional comparisons and spatial and temporal comparisons, and the application of remote sensing technology in farmland abandonment needs to be strengthened, especially in the spatial identification, data information extraction and multiscale simulation monitoring of farmland abandonment. Due to China's vast territory, farmer survey data are susceptible to bias in sample size and sampling methods, which can distort survey results. In addition, the fragmentation and abandonment of farmland in mountainous areas is serious, which makes it more difficult to obtain information on farmland in mountainous areas. Therefore, it is urgent to develop remote sensing survey technology suitable for obtaining information on abandoned land in mountainous areas to improve the accuracy and timeliness of information extraction.

It should be noted that although many studies have simulated and predicted the temporal and spatial trends of farmland abandonment. However, there is still an insufficient number of studies on the interaction mechanism between macro and micro, trend prediction and risk assessment in farmland abandonment, especially in China and other developing countries. China and other such countries are undergoing a process of socioeconomic system transformation and rapid development, and farmland abandonment is rapidly emerging and changing. Therefore, it is urgent that a prediction model and risk assessment mechanism be built for farmland abandonment on the basis of research on the influencing factors and mechanisms of farmland abandonment to monitor the trend of farmland abandonment at any time, accurately determine the geographical location of farmland abandonment, assess the possible ecological and environmental consequences after deforestation and provide a basis for the government to formulate effective response strategies.

\section{Conclusions}

According to the theme strategy map and clustering network map of each research time period, the evolution capability and status of each research theme were identified. Second, using the perspective of data flow, the topic coverage map and evolution map were further analyzed to identify the evolution of new and old research topics in the four research time periods. Finally, combining the themes' evolution paths and strategic distributions, the following characteristics for research on farmland abandonment were identified:

(1) The research literature on the subject of research on farmland abandonment was slowly, but steadily growing before 2011, and it increased linearly after 2012. Although there was a decline in the related literature on farmland abandonment in 2017, the volume of related literature in 2018 increased sharply to 172 publications, 49 more than in 2017 and 20 fewer than in 2019. From the perspective of the change of theme keywords, early research was slow, there were few research keywords, and the popularity of the subject was low; in later periods, the number of theme keywords increased, showing a diversified development. From the perspective of the theme evolution stability index, the development of farmland abandonment research matured, and there was also a tendency for research topics and research content to solidify.

(2) From the perspective of theme evolution, the hot theme have been forest, pattern, landscape, land-use-change and climate-change, and these research hot themes emerged in two research time periods: 2005-2011 and 2012-2016. However, the frequency of new research hot spots is low, the research perspective lacks novelty, and the research methods need to be updated. 
(3) From the perspective of the theme evolution path, the research themes of farmland abandonment are divided into three categories and have evolved along five paths. The three directions are the study of landscapes and eco-environment effects, the study of land use change and ecosystem processes and the influencing factors of farmland abandonment. Among these paths, the study of landscapes and eco-environmental effects is a basic research direction in the field of the abandonment of farmland and will continue to be a research hotspot. The study of land use change and ecosystem processes has obvious themes of fusion and fragmentation in the evolution process and a strong evolutionary capacity, and research on farmland abandonment has become an important part of this study. The research devoted to the influencing factors of farmland abandonment appeared relatively late in the field of farmland abandonment, but its development was rapid, attention to it has increased and it has great development potential in the future.

Author Contributions: H.X. conceptualized the research and performed the validation. Y.H. and F.L. administered the project, developed the methodology, produced visualizations. Y.H. curated the data, conducted the formal analysis and wrote and prepared the original draft manuscript. H.X. and Y.H. reviewed and edited the manuscript. H.X. acquired funding. All authors have read and agreed to the published version of the manuscript.

Funding: This study was supported by the National Natural Science Foundation of China (No. 41971243 \& No. 41930757); the Academic and Technical Leaders Funding Program for Major Disciplines in Jiangxi Province (No. 20172BCB22011); the Fok Ying-Tung Fund (No. 141,084).

Acknowledgments: The authors would like to thank the four anonymous reviewers and the editor whose suggestions greatly improved the manuscript.

Conflicts of Interest: The authors declare no conflicts of interest.

\section{References}

1. Xu, D.D.; Deng, X.; Guo, S.L.; Liu, S.Q. Labor migration and farmland abandonment in rural China: Empirical results and policy implications. J. Environ. Manag. 2019, 232, 738-750. [CrossRef]

2. Hao, H.G.; Li, X.B.; Zhang, H.Y.; Zhang, J.; Tan, M. Impact of the opportunity cost of farming labor on the agricultural land marginalization. Arid Land Res. Environ. 2015, 29, 50-56. (In Chinese) [CrossRef]

3. Li, S.F.; Li, X.B. Progress and prospect on farmland abandonment. Acta Geogr. Sin. 2016, 71, 370-389. (In Chinese) [CrossRef]

4. Gellrich, M.; Zimmermann, N.E. Investigating the regional-scale pattern of agricultural land abandonment in the Swiss mountains: A spatial statistical modelling approach. Landsc. Urban Plan. 2007, 79, 65-76. [CrossRef]

5. Baumann, M.; Kuemmerle, T.; Elbakidze, M.; Ozdogan, M.; Radeloff, V.C.; Keuler, N.S.; Prishchepov, A.V.; Kruhlov, I.; Hostert, P. Patterns and drivers of post-socialist farmland abandonment in Western Ukraine. Land Use Policy 2011, 28, 552-562. [CrossRef]

6. Keenleyside, C.; Tucker, G. Farmland Abandonment in the EU: An Assessment of Trends and Prospects. Report Prepared for WWF; Institute for European Environmental Policy: London, UK, 2010.

7. Lambin, E.F.; Meyfroidt, P. Land use transitions: Socio-ecological feedback versus socio-economic change. Land Use Policy 2010, 27, 108-118. [CrossRef]

8. Terres, J.; Nisini, L.; Anguiano, E. Assessing the Risk of Farmland Abandonment in the EU; European Commission Joint Research Centre, Institute for Environment and Sustainability: Ispra, Italy, 2013.

9. Rudel, T.K. Tree farms: Driving forces and regional patterns in the global expansion of forest plantations. Land Use Policy 2009, 26, 545-550. [CrossRef]

10. Cramer, V.A.; Hobbs, R.J.; Standish, R.J. What's new about old fields? Land abandonment and ecosystem assembly. Trends Ecol. Evol. 2008, 23, 104-112. [CrossRef]

11. Schierhorn, F.; Müller, D.; Beringer, T.; Prishchepov, A.V.; Kuemmerle, T.; Balmann, A. Post-Soviet cropland abandonment and carbon sequestration in European Russia, Ukraine, and Belarus. Glob. Biogeochem. Cycles 2013, 27, 1175-1185. [CrossRef]

12. Dunn, R. Recovery of faunal communities during tropical forest regeneration. Conserv. Biol. 2004, 18, 302-309. [CrossRef] 
13. Benayas, J.; Martins, A.; Nicolaul, J.; Shulz, J.J. Abandonment of agricultural land: An overview of drivers and consequences. CAB Rev. Perspect. Agric. Veter. Sci. Nutr. Nat. Resour. 2007, 2. [CrossRef]

14. Pepe, G.; Mandarino, A.; Raso, E.; Scarpellini, P.; Brandolini, P.; Cevasco, A. Investigation on Farmland Abandonment of Terraced Slopes Using Multitemporal Data Sources Comparison and Its Implication on Hydro-Geomorphological Processes. Water 2019, 11, 1552. [CrossRef]

15. Gariano, S.L.; Petrucci, O.; Rianna, G.; Santini, M.; Guzzetti, F. Impacts of past and future land changes on landslides in southern Italy. Reg. Environ. Chang. 2018, 18, 437-449. [CrossRef]

16. Dubinin, M.Y.; Potapov, P.; Lushchekina, A.; Radeloff, V.C. Reconstructing long time series of burned areas in arid grasslands of southern Russia by satellite remote sensing. Remote Sens. Environ. 2010, 114, 1638-1648. [CrossRef]

17. García-Ruiz, J.M.; Lana-Renault, N. Hydrological and erosive consequences of farmland abandonment in Europe, with special reference to the Mediterranean region: A review. Agric. Ecosyst. Environ. 2011, 140, 317-338. [CrossRef]

18. Stoate, C.; Baldi, A.; Beja, P.; Boatman, N.; Herzon, I.; Van Doorn, A.; De Snoo, G.; Rakosy, L.; Ramwell, C. Ecological impacts of early 21st century agricultural change in Europe: A review. J. Environ. Manag. 2009, 91, 22-46. [CrossRef]

19. Fischer, J.; Hartel, T.; Kuemmerle, T. Conservation policy in traditional farming landscapes. Conserv. Lett. 2012, 5, 167-175. [CrossRef]

20. Cavani, L.; Manici, L.M.; Caputo, F.; Peruzzi, E.; Ciavatta, C. Ecological restoration of a copper polluted vineyard: Long-term impact of farmland abandonment on soil bio-chemical properties and microbial communities. J. Environ. Manag. 2016, 182, 37-47. [CrossRef]

21. Londoño, A.C.; Williams, P.R.; Hart, M.L. A change in landscape: Lessons learned from abandonment of ancient Wari agricultural terraces in Southern Peru. J. Environ. Manag. 2017, 202, 32-42. [CrossRef]

22. Deng, X.; Xu, D.D.; Zeng, M.; Qi, Y. Landslides and Cropland Abandonment in China's Mountainous Areas: Spatial Distribution, Empirical Analysis and Policy Implications. Sustainability 2018, 10, 3909. [CrossRef]

23. Macdonald, D.; Crabtree, J.; Wiesinger, G.; Dax, T.; Stamou, N.; Fleury, P.; Lazpita, J.G.; Gibon, A. Agricultural abandonment in mountain areas of Europe: Environmental consequences and policy response. J. Environ. Manag. 2000, 59, 47-69. [CrossRef]

24. Renwick, A.W.; Jansson, T.; Verburg, P.H.; Revoredo-Giha, C.; Britz, W.; Gocht, A.; McCracken, D.I. Policy reform and agricultural land abandonment in the EU. Land Use Policy 2013, 30, 446-457. [CrossRef]

25. Falcucci, A.; Maiorano, L.; Boitani, L. Changes in land-use/land-cover patterns in Italy and their implications for biodiversity conservation. Landsc. Ecol. 2007, 22, 617-631. [CrossRef]

26. Doorn, A.; Bakker, M. The destination of arable land in a marginal agricultural landscape in South Portugal: An exploration of land use change determinants. Landsc. Ecol. 2007, 22, 73-87. [CrossRef]

27. Tasser, E.; Walde, J.; Tappeiner, U.; Teutsch, A.; Noggler, W. Land-use changes and natural reforestation in the Eastern Central Alps. Agric. Ecosyst. Environ. 2007, 118, 115-129. [CrossRef]

28. Reger, B.; Otte, A.; Waldhardt, R. Identifying patterns of land-cover change and their physical attributes in a marginal European landscape. Landsc. Urban Plan. 2007, 81, 104-113. [CrossRef]

29. Foucher, A.; Evrard, O.; Chabert, C.; Cerdan, O.; Lefèvre, I.; Vandromme, R.; Salvador-Blanes, S. Erosional response to land abandonment in rural areas of Western Europe during the Anthropocene: A case study in the Massif-Central, France. Agric. Ecosyst. Environ. 2019, 284, 106582. [CrossRef]

30. Lieskovský, J.; Bezák, P.; Špulerová, J.; Lieskovský, T.; Koleda, P.; Dobrovodská, M.; Bürgi, M.; Gimmi, U. The abandonment of traditional agricultural landscape in Slovakia-Analysis of extent and driving forces. J. Rural. Stud. 2015, 37, 75-84. [CrossRef]

31. Aide, T.M.; Grau, H.R. Globalization, Migration, and Latin American Ecosystems. Science 2004, 305, $1915-1916$. [CrossRef]

32. Beilin, R.; Lindborg, R.; Stenseke, M.; Pereira, H.M.; Llausàs, A.; Slätmo, E.; Cerqueira, Y.; Navarro, L.M.; Rodrigues, P.; Reichelt, N.; et al. Analysing how drivers of agricultural land abandonment affect biodiversity and cultural landscapes using case studies from Scandinavia, Iberia and Oceania. Land Use Policy 2014, 36, 60-72. [CrossRef]

33. Kamada, M.; Nakagoshi, N. Influence of cultural factors on landscapes of mountainous farm villages in western Japan. Landsc. Urban Plan. 1997, 37, 85-90. [CrossRef] 
34. Melendez-Pastor, I.; Hernández, E.I.; Pedreño, J.N.; Gomez, I. Socioeconomic factors influencing land cover changes in rural areas: The case of the Sierra de Albarracín (Spain). Appl. Geogr. 2014, 52, 34-45. [CrossRef]

35. Zhang, X.; Zhao, C.; Dong, J.; Quansheng, G.E. Spatio-temporal pattern of cropland abandonment in China from 1992 to 2017: A Meta-analysis. Acta Geogr. Sin. 2019, 74, 411-420. (In Chinese) [CrossRef]

36. López-Herrera, A.G.; Cobo, M.-J.; Herrera-Viedma, E.; Herrera, F. A bibliometric study about the research based on hybridating the fuzzy logic field and the other computational intelligent techniques: A visual approach. Int. J. Hybrid Intell. Syst. 2010, 7, 17-32. [CrossRef]

37. Cobo, M.-J.; López-Herrera, A.G.; Herrera-Viedma, E.; Herrera, F. An approach for detecting, quantifying, and visualizing the evolution of a research field: A practical application to the Fuzzy Sets Theory field. J. Inf. 2011, 5, 146-166. [CrossRef]

38. Cobo, M.J.; Herrera-Viedma, E.; Herrera, F.; López-Herrera, A. SciMAT: A new science mapping analysis software tool. J. Am. Soc. Inf. Sci. Technol. 2012, 63, 1609-1630. [CrossRef]

39. Cobo, M.J.; Lopez-Herrera, A.G.; Herrera, F.; Herrera-Viedma, E. A Note on the ITS Topic Evolution in the Period 2000-2009 at T-ITS. IEEE Trans. Intell. Transp. Syst. 2011, 13, 413-420. [CrossRef]

40. Levy, H. Peasant Issue and Land Abandonment in England. Archiv Fur Soziale Gesetzgebung Und Statistik 1903, 18, 483-518.

41. Wolfanger, L.A. Abandoned Land in a region of land abandonment. Econ. Geogr. 1931, 7, 166-176. [CrossRef]

42. Van Eetvelde, V.; Antrop, M. Analyzing structural and functional changes of traditional landscapesTwo examples from Southern France. Landsc. Urban Plan. 2004, 67, 79-95. [CrossRef]

43. Fukamachi, K.; Oku, H.; Nakashizuka, T. The change of a satoyama landscape and its causality in Kamiseya, Kyoto Prefecture, Japan between 1970 and 1995. Landsc. Ecol. 2002, 16, 703-717. [CrossRef]

44. Suarez-Seoane, S.; Baudry, J. Scale dependence of spatial patterns and cartography on the detection of landscape change: Relationships with species' perception. Ecography 2002, 25, 499-511. [CrossRef]

45. Sang, N.; Dramstad, W.E.; Bryn, A. Regionality in Norwegian farmland abandonment: Inferences from production data. Appl. Geogr. 2014, 55, 38-47. [CrossRef]

46. Rønningen, K. Agricultural policies and landscape management. Some examples from Norway, Great Britain and Germany. Nor. J. Geogr. 1993, 47, 93-104. [CrossRef]

47. Fjellstad, W.J.; Dramstad, W.E. Patterns of change in two contrasting Norwegian agricultural landscapes. Landsc. Urban Plan. 1999, 45, 177-191. [CrossRef]

48. Muller, S. Introductive report to the symposium "Biodiversity and Grassland Management": Determinism and evolution of biodiversity in grassland ecosystems. Acta Bot. Gallica 1996, 143, 233-238. [CrossRef]

49. Laiolo, P.; Rolando, A.; Valsania, V. Responses of birds to the natural re-establishment of wilderness in montane beechwoods of North-western Italy. Acta Oecol. 2004, 25, 129-136. [CrossRef]

50. Staaland, H.; Holand, Ø.; Nellemann, C.; Smith, M. Time scale for forest regrowth: Abandoned grazing and agricultural areas in southern Norway. Ambio 1998, 27, 456-460.

51. Verburg, P.H.; Vaneck, J.R.R.; Denijst, C.M.; Dijst, M.J.; Schot, P. Determinants of Land-Use Change Patterns in the Netherlands. Environ. Plan. B Plan. Des. 2004, 31, 125-150. [CrossRef]

52. Rutherford, G.N.; Bebi, P.; Edwards, P.J.; Zimmermann, N.E. Assessing land-use statistics to model land cover change in a mountainous landscape in the European Alps. Ecol. Model. 2008, 212, 460-471. [CrossRef]

53. Burgi, M.; Turner, M.G. Factors and processes shaping land cover and land cover changes along the Wisconsin River. Ecosystems 2002, 5, 184-201. [CrossRef]

54. Ramankutty, N.; Foley, J.A. Estimating historical changes in land cover: North American croplands from 1850 to 1992. Glob. Ecol. Biogeogr. 1999, 8, 381-396. [CrossRef]

55. Soares, B.; Alencar, A.; Nepstad, D.; Cerqueira, G.; Vera-Diaz, M.D.C.; Rivero, S.; Solórzano, L.; Voll, E. Simulating the response of land-cover changes to road paving and governance along a major Amazon highway: The Santarem-Cuiaba corridor. Glob. Chang. Biol. 2004, 10, 745-764. [CrossRef]

56. Cammeraat, L.H.; Imeson, A.C. The evolution and significance of soil-vegetation patterns following land abandonment and fire in Spain. Catena 1999, 37, 107-127. [CrossRef]

57. Lookingbill, T.R.; Zavala, M.A. Spatial pattern of Quercus ilex and Quercus pubescens recruitment in Pinus halepensis dominated woodlands. J. Veg. Sci. 2000, 11, 607-612. [CrossRef]

58. Alves, D.S.; Soares, J.V.; Amaral, S.; Mello, E.; Almeida, S.; Da Silva, O.F.; Silveira, A. Biomass of primary and secondary vegetation in Rondonia, Western Brazilian Amazon. Glob. Chang. Biol. 1997, 3, 451-461. [CrossRef] 
59. Brown, D.G. Land use and forest cover on private parcels in the Upper Midwest USA, 1970 to 1990. Landsc. Ecol. 2003, 18, 777-790. [CrossRef]

60. Lasanta, T.; Begueria, S.; Garcia, R.J.M. Geomorphic and hydrological effects of traditional shifting agriculture in a Mediterranean mountain area, central Spanish Pyrenees. Mt. Res. Dev. 2006, 26, 146-152. [CrossRef]

61. Symeonakis, E.; Calvo-cases, A.; Arnau-rosalen, E. Land use change and land degradation in southeastern Mediterranean Spain. Environ. Manag. 2007, 40, 80-94. [CrossRef]

62. Martinez, J.; Vega-Garcia, C.; Chuvieco, E. Human-caused wildfire risk rating for prevention planning in Spain. J. Environ. Manag. 2009, 90, 1241-1252. [CrossRef]

63. Grigulis, K.; Lavorel, S.; Davies, I.D.; DosSantos, A.; Lloret, F.; Vilà, M. Landscape-scale positive feedbacks between fire and expansion of the large tussock grass, Ampelodesmos mauritanica in Catalan shrublands. Glob. Chang. Biol. 2005, 11, 1042-1053. [CrossRef]

64. Vega-Garcia, C.; Chuvieco, E. Applying local measures of spatial heterogeneity to Landsat-TM images for predicting wildfire occurrence in mediterranean landscapes. Landsc. Ecol. 2006, 21, 595-605. [CrossRef]

65. Koulouri, M.; Giourga, C. Land abandonment and slope gradient as key factors of soil erosion in Mediterranean terraced lands. Catena 2007, 69, 274-281. [CrossRef]

66. Arnaez, J.; Lasanta, T.; Errea, M.P.; Ortigosa, L. Land abandonment, landscape evolution, and soil erosion in a Spanish Mediterranean mountain region: The case of Camero Viejo. Land Degrad. Dev. 2011, 22, 537-550. [CrossRef]

67. Gil-tena, A.; Brotons, L.; Saura, S. Mediterranean forest dynamics and forest bird distribution changes in the late 20th century. Glob. Chang. Biol. 2009, 15, 474-485. [CrossRef]

68. Hatna, E.; Bakker, M.M. Abandonment and Expansion of Arable Land in Europe. Ecosystems 2011, 14, 720-731. [CrossRef]

69. Verburg, P.H.; Overmars, K.P. Combining top-down and bottom-up dynamics in land use modeling: Exploring the future of abandoned farmlands in Europe with the Dyna-CLUE model. Landsc. Ecol. 2009, 24, 1167-1181. [CrossRef]

70. Moreira, F.; Russo, D. Modelling the impact of agricultural abandonment and wildfires on vertebrate diversity in Mediterranean Europe. Landsc. Ecol. 2007, 22, 1461-1476. [CrossRef]

71. Sirami, C.; Brotons, L.; Martin, J.L. Vegetation and songbird response to land abandonment: From landscape to census plot. Divers. Distrib. 2007, 13, 42-52. [CrossRef]

72. Kuemmerle, T.; Hostert, P.; Radeloff, V.C.; Van Der Linden, S.; Perzanowski, K.; Kruhlov, I. Cross-border comparison of post-socialist farmland abandonment in the Carpathians. Ecosystems 2008, 11, 614-628. [CrossRef]

73. Baur, B.; Cremene, C.; Groza, G.; Rákosy, L.; Schileyko, A.A.; Baur, A.; Stoll, P.; Erhardt, A.; Craioveanu, C. Effects of abandonment of subalpine hay meadows on plant and invertebrate diversity in Transylvania, Romania. Biol. Conserv. 2006, 132, 261-273. [CrossRef]

74. Flinn, K.M.; Vellend, M.; Marks, P.L. Environmental causes and consequences of forest clearance and agricultural abandonment in central New York, USA. J. Biogeogr. 2005, 32, 439-452. [CrossRef]

75. Gehrig-Fasel, J.; Guisan, A.; Zimmermann, N.E. Tree line shifts in the Swiss Alps: Climate change or land abandonment? J. Veg. Sci. 2007, 18, 571-582. [CrossRef]

76. Ramankutty, N.; Heller, E.; Rhemtulla, J. Prevailing Myths About Agricultural Abandonment and Forest Regrowth in the United States. Ann. Assoc. Am. Geogr. 2010, 100, 502-512. [CrossRef]

77. Kuemmerle, T.; Olofsson, P.; Chaskovskyy, O.; Baumann, M.; Ostapowicz, K.; Woodcock, C.E.; Houghton, R.A.; Hostert, P.; Keeton, W.S.; Radeloff, V.C. Post-Soviet farmland abandonment, forest recovery, and carbon sequestration in western Ukraine. Glob. Chang. Biol. 2011, 17, 1335-1349. [CrossRef]

78. Sirami, C.; Brotons, L.; Martin, J.L. Woodlarks Lullula arborea and landscape heterogeneity created by land abandonment. Bird Study 2011, 58, 99-106. [CrossRef]

79. Prishchepov, A.V.; Radeloff, V.C.; Baumann, M.; Kuemmerle, T.; Müller, D. Effects of institutional changes on land use: Agricultural land abandonment during the transition from state-command to market-driven economies in post-Soviet Eastern Europe. Environ. Res. Lett. 2012, 7, 024021. [CrossRef]

80. Muller, D.; Lettao, P.J.; Sikor, T. Comparing the determinants of cropland abandonment in Albania and Romania using boosted regression trees. Agric. Syst. 2013, 117, 66-77. [CrossRef]

81. Prishchepov, A.V.; Muller, D.; Dubinin, M.; Baumann, M.; Radeloff, V.C. Determinants of agricultural land abandonment in post-Soviet European Russia. Land Use Policy 2013, 30, 873-884. [CrossRef] 
82. Lieskovsky, J.; Kanka, R.; Bezak, P.; Štefunková, D.; Petrovič, F.; Dobrovodská, M. Driving forces behind vineyard abandonment in Slovakia following the move to a market-oriented economy. Land Use Policy 2013, 32, 356-365. [CrossRef]

83. Meyfroidt, P.; Schierhorn, F.; Prishchepov, A.V.; Müller, D.; Kuemmerle, T. Drivers, constraints and trade-offs associated with recultivating abandoned cropland in Russia, Ukraine and Kazakhstan. Glob. Environ. Chang. 2016, 37, 1-15. [CrossRef]

84. Latocha, A.; Szymanowski, M.; Jeziorska, J.; Stec, M.; Roszczewska, M. Effects of land abandonment and climate change on soil erosion-An example from depopulated agricultural lands in the Sudetes Mts., SW Poland. Catena 2016, 145, 28-41. [CrossRef]

85. Navarro, L.M.; Pereira, H.M. Rewilding Abandoned Landscapes in Europe. Ecosystems 2012, 15, $900-912$. [CrossRef]

86. Uchida, K.; Ushimaru, A. Biodiversity declines due to abandonment and intensification of agricultural lands: Patterns and mechanisms. Ecol. Monogr. 2014, 84, 637-658. [CrossRef]

87. Hinojosa, L.; Napoleone, C.; Moulery, M.; Lambin, E.F. The "mountain effect" in the abandonment of grasslands: Insights from the French Southern Alps. Agric. Ecosyst. Environ. 2016, 221, 15-24. [CrossRef]

88. Xu, D.; Guo, S.; Xie, F.; Liu, S.; Cao, S. The impact of rural laborer migration and household structure on household land use arrangements in mountainous areas of Sichuan Province, China. Habitat Int. 2017, 70, 72-80. [CrossRef]

89. Yan, J.; Yang, Z.; Li, Z.H.; Li, X.; Xin, L.; Sun, L. Drivers of cropland abandonment in mountainous areas: A household decision model on farming scale in Southwest China. Land Use Policy 2016, 57, 59-69. [CrossRef]

90. Zhang, L.; Tan, S.K.; Liu, C.W.; Wang, S. Influence of labor transfer on farmland sustainable development: A regional comparison of plain and hilly areas. Qual. Quant. 2018, 52, 431-443. [CrossRef]

91. Zhang, Y.; Li, X.B.; Song, W. Determinants of cropland abandonment at the parcel, household and village levels in mountain areas of China: A multi-level analysis. Land Use Policy 2014, 41, 86-92. [CrossRef]

92. Zhang, B.L.; Yang, Q.Y.; Yan, Y.; Xue, M.; Su, K.C.; Zang, B. Characteristics and Reasons of Different Households' Farming Abandonment Behavior in the Process of Rapid Urbanization Based on a Survey from 540 Households in 10 Counties of Chongqing Municipality. Res. Sci. 2011, 33, 2047-2054. (In Chinese)

93. Sklenicka, P.; Kottová, B.; Šálek, M. Success in preserving historic rural landscapes under various policy measures: Incentives, restrictions or planning? Environ. Sci. Policy 2017, 75, 1-9. [CrossRef]

94. Blair, D.; Shackleton, C.M.; Mograbi, P.J. Cropland Abandonment in South African Smallholder Communal Lands: Land Cover Change (1950-2010) and Farmer Perceptions of Contributing Factors. Land 2018, 7, 121. [CrossRef]

95. Estruch, C.; Lozano, Y.M.; Armas, C.; Pugnaire, F.I. Plant community changes after land abandonment control CO2 balance in a dry environment. Plant Soil 2018, 425, 253-264. [CrossRef]

96. Deguchi, S.; Ishihara, Y.; Miguchi, H. Habitat preferences of breeding Yellow Buntings Emberiza sulphurata in hilly rural areas following rice field abandonment in northern Japan. Bird Conserv. Int. 2016, 27, 550-559. [CrossRef]

97. Chemini, C.; Rizzoli, A. Land use change and biodiversity conservation in the Alps. J. Mt. Ecol. 2003, 7, 1-7.

98. Dullinger, S.; Dirnböck, T.; Greimler, J.; Grabherr, G. A resampling approach for evaluating effects of pasture abandonment on subalpine plant species diversity. J. Veg. Sci. 2003, 14, 243-252. [CrossRef]

99. García, F.E.; Ayala-orozco, B.; Bonilla-moheno, M.; Espadas-Manrique, C.; Ramos-Fernández, G. Biodiversity conservation, traditional agriculture and ecotourism: Land cover/land use change projections for a natural protected area in the northeastern Yucatan Peninsula, Mexico. Landsc. Urban Plan. 2007, 83, 137-153. [CrossRef]

100. Katoh, K.; Sakai, S.; Takahashi, T. Factors maintaining species diversity in satoyama, a traditional agricultural landscape of Japan. Biol. Conserv. 2009, 142, 1930-1936. [CrossRef]

101. Doxa, A.; Bas, Y.; Paracchini, M.L.; Pointereau, P.; Terres, J.-M.; Jiguet, F. Low-intensity agriculture increases farmland bird abundances in France. J. Appl. Ecol. 2010, 47, 1348-1356. [CrossRef]

102. Terres, J.M.; Scacchiafichi, L.N.; Wania, A.; Ambar, M.; Anguiano, E.; Buckwell, A.; Coppola, A.; Gocht, A.; Källström, H.N.; Pointereau, P.; et al. Farmland abandonment in Europe: Identification of drivers and indicators, and development of a composite indicator of risk. Land Use Policy 2015, 49, 20-34. [CrossRef] 
103. Sirami, C.; Jay-Robert, P.; Brustel, H.; Lionel, V.; Martin, J.-L. Saproxylic beetle assemblages of old Holm-oak trees in the Mediterranean region: Role of a keystone structure in a changing heterogeneous landscape. Rev. D Ecol. 2008, 10, 101-114.

104. Gellrich, M.; Baur, P.; Koch, B.; Zimmermann, N.E. Agricultural land abandonment and natural forest re-growth in the Swiss mountains: A spatially explicit economic analysis. Agric. Ecosyst. Environ. 2007, 118, 93-108. [CrossRef]

105. Batlle-baye, L.; Batjes, N.H.; Bindraban, P.S. Changes in organic carbon stocks upon land use conversion in the Brazilian Cerrado: A. review. Agric. Ecosyst. Environ. 2010, 137, 47-58. [CrossRef]

106. Munroe, D.K.; Berkel, V.D.B.; Verburg, P.H.; Olson, J.L. Alternative trajectories of land abandonment: Causes, consequences and research challenges. Curr. Opin. Environ. Sustain. 2013, 5, 471-476. [CrossRef]

107. Dara, A.; Baumann, M.; Kuemmerle, T.; Pflugmacher, D.; Rabe, A.; Griffiths, P.; Hölzel, N.; Kamp, J.; Freitag, M.; Hostert, P. Mapping the timing of cropland abandonment and recultivation in northern Kazakhstan using annual Landsat time series. Remote Sens. Environ. 2018, 213, 49-60. [CrossRef]

108. Molinillo, M.; Lasanta, T.; Garciaruiz, J.M. Managing mountainous degraded landscapes after farmland abandonment in the central Spanish pyrenees. Environ. Manag. 1997, 21, 587-598. [CrossRef]

109. Bakker, M.M.; Govers, G.; Doom, V.A.; Quétier, F.; Chouvardas, D.; Rounsevell, M. The response of soil erosion and sediment export to land-use change in four areas of Europe: The importance of landscape pattern. Geomorphology 2008, 98, 213-226. [CrossRef]

110. Giupponai, C.; Ramanzin, M.; Sturaro, E.; Fuser, S. Climate and land use changes, biodiversity and agri-environmental measures in the Belluno province, Italy. Environ. Sci. Policy 2006, 9, 163-173. [CrossRef]

111. Uematsu, Y.; Koga, T.; Mitsuhashi, H.; Ushimaru, A. Abandonment and intensified use of agricultural land decrease habitats of rare herbs in semi-natural grasslands. Agric. Ecosyst. Environ. 2010, 135, 304-309. [CrossRef]

112. Padilla, F.M.; Vidal, B.; Sanghez, J.; Pugnaire, F.I. Land-use changes and carbon sequestration through the twentieth century in a Mediterranean mountain ecosystem: Implications for land management. J. Environ. Manag. 2010, 91, 2688-2695. [CrossRef]

113. Gong, J.; Chen, L.; Fu, B.; Huang, Y.; Huang, Z.; Peng, H. Effect of land use on soil nutrients in the loess hilly area of the Loess Plateau, China. Land Degrad. Dev. 2006, 17, 453-465. [CrossRef]

114. Müller, D.; Sikor, T. Effects of postsocialist reforms on land cover and land use in South-Eastern Albania. Appl. Geogr. 2006, 26, 175-191. [CrossRef]

115. Strijker, D. Marginal lands in Europe-causes of decline. Basic Appl. Ecol. 2005, 6, 99-106. [CrossRef]

116. Lesschen, J.P.; Kok, K.; Verburg, P.H.; Cammeraat, L. Identification of vulnerable areas for gully erosion under different scenarios of land abandonment in Southeast Spain. Catena 2007, 71, 110-121. [CrossRef]

117. Corbelle, R.E.; Crecente-Maseda, R.; Sante-Riveira, I. Multi-scale assessment and spatial modelling of agricultural land abandonment in a European peripheral region: Galicia (Spain), 1956-2004. Land Use Policy 2012, 29, 493-501. [CrossRef]

118. LöW, F.; Fliemann, E.; Abdullaev, I.; Conrad, C.; Lamers, J.P. Mapping abandoned agricultural land in Kyzyl-Orda, Kazakhstan using satellite remote sensing. Appl. Geogr. 2015, 62, 77-90. [CrossRef]

119. Suziedelyte, V.J.; Tumeliene, E.; Maliene, V. Analysis and identification of abandoned agricultural land using remote sensing methodology. Land Use Policy 2019, 82, 709-715. [CrossRef]

(C) 2020 by the authors. Licensee MDPI, Basel, Switzerland. This article is an open access article distributed under the terms and conditions of the Creative Commons Attribution (CC BY) license (http://creativecommons.org/licenses/by/4.0/). 